\title{
Change and Transformation in Asian Industrial Relations
}

\section{SAROSH KURUVILLA and CHRISTOPHER L. ERICKSON*}

\begin{abstract}
We argue that industrial relations (IR) systems change due to shifts in the constraints facing those systems and that the most salient constraints facing IR systems in Asia have shifted from those of maintaining labor peace and stability in the early stages of industrialization to those of increasing both numerical and functional flexibility in the 1980s and 1990s. The evidence to sustain this argument is drawn from seven "representative" Asian IR systems: Japan, South Korea, Singapore, Malaysia, the Philippines, India, and China. We also distinguish between systems that have smoothly adapted (Singapore, Malaysia, and the Philippines) and systems that have fundamentally transformed (China and South Korea) and hypothesize about the reasons for this difference.
\end{abstract}

JUDGING FROM THE ATTENTION PAID BY RESEARCHERS, it would seem that the 1980s and 1990s were a period of change, turmoil, and even transformation in industrial relations (IR) systems all over the world. Much of this literature has been based on evidence from the advanced industrial nations (e.g., Locke 1996; Katz 1993; Kochan, Katz, and McKersie 1986; Streeck 1988; Frenkel 1988; Bray and Haworth 1993; Armingeon 1994). While there are dissenting views about whether IR has in fact transformed in these nations (e.g., Golden, Wallerstein, and Lange 1997, Crouch 1993, Hyman 1994) and there have been attempts to make distinctions between

*The authors' affiliations are Cornell University and the Anderson Graduate School of Management at the University of California, Los Angeles. E-mail: sck4@cornell.edu and cerickso@anderson.ucla.edu. We thank Harry Katz, Stephen Frenkel, Sanford Jacoby, Rong Jiang, Seongsu Kim, Subesh Das, Hyunji Kwon, Soon-won Kwon, and Debashish Bhattacherjee for comments on an earlier version of this article, Ina Ortiz and Zeynep Aksehirli for research assistance, and three anonymous referees for their excellent comments.

Industrial Relations, Vol. 41, No. 2 (April 2002). (C) 2002 Regents of the University of California Published by Blackwell Publishing, Inc. 350 Main Street, Malden, MA 02148, USA, and 108 Cowley Road, Oxford, OX4 IJF, UK. 
transformation and nonfundamental change (e.g., Erickson and Kuruvilla 1998a), there is broad agreement on the main factor driving these changes: increasingly competitive environments caused by the integration of world markets, as well as the direction of the change: decentralization of bargaining, and a movement toward increased flexibility in wages, labor deployment, and at the workplace level.

Relatively less attention has been paid to how IR systems have changed in the developing nations of Asia, Latin America, and Africa, with some exceptions. ${ }^{1}$ Given that several Asian countries have seen considerable changes in their IR systems in the 1990s, the goal of this article is to attempt to understand the nature of the changes and to evaluate whether or not they amount to fundamental transformations. The similarity in the timing of change in Asian IR systems with that of the West (both occurred in late 1980 s and early 1990s) raises the possibility that there are universal driving forces, although idiosyncratic national forces presumably also are at work. If in fact the forces driving change in the West (primarily increased competitive pressures) operate globally, then one would expect Asian IR systems to be most likely to evidence changes (relative to African or Latin American IR systems), given that Asian nations generally are more exposed to the global economy (World Bank 1998). ${ }^{2}$

To facilitate this investigation, we first propose an argument regarding IR system change. We then examine the extent to which Asian IR systems are changing and whether the directions of change are similar to those we have seen in the advanced industrial countries outside the region. Thereafter, we characterize the key features of IR change, including whether or not the changes constitute fundamental transformations, based on recent work regarding how to judge whether a transformation has indeed taken place (Erickson and Kuruvilla 1998a).

Given that an exhaustive review of all Asian IR systems is beyond the scope of one article, we focus on representative systems. Kuruvilla and Venkitaratnam (1996) argue that IR systems in Asia are typified by six distinct stylized models: the Japanese flexible-workplace model, the

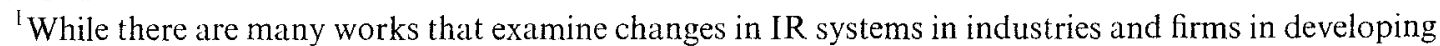
countries, relatively few have studied IR systems change across countries. See Frenkel and Peetz (1998), Kuruvilla (1996), and Cook (1996) for some examples.

${ }^{2}$ Asia's overall trade with the advanced industrial world is higher than that of Latin America or Africa, and Asia has taken the lion's share of the foreign direct investment to date from the advanced industrial nations. Moreover, on contemporary measures of openness (e.g., average tariffs, exports/ imports as a percentage of gross domestic product, and FDI as a percentage of gross fixed capital formation), Asian economies, on average, score significantly higher than their counterparts in the other developing regions. These data are available in the World Investment Report and several other publications from UNCTAD.
} 
tripartite Singapore model, the state-employer-dominated model (Malaysia and Indonesia), the pluralist decentralized and fragmented IR model (the Philippines), the politicized multiunion model (India and the rest of South Asia), and the transitory model (a catch-all category that includes South Korea, Taiwan, China, and Vietnam). Note that the transitory model takes into account transitions from authoritarian rule to democracy (South Korea and Taiwan) as well as from closed to more open economies (China and Vietnam) during the last decades.

Therefore, we examine IR systems change in seven countries that conform closely to each of these models: Japan, South Korea, Singapore, Malaysia, the Philippines, India, and China. Not only are these countries representative of the Asian region in general terms (they constitute the majority of Asian gross domestic product and population), but they also represent the range of IR systems and they provide a good representation of the different levels of economic development within Asia (with Japan being an advanced industrialized country; South Korea and Singapore being newly industrialized countries, also known as "Tigers"; Malaysia and the Philippines being newly emerging industrial nations; and India and China having opened their doors to the world economy only recently).

Our focus is primarily on the unionized sector in each country. In most cases, this sector is a relatively small percentage of the total workforce (union densities in the countries in our sample vary from 6 to 19 percent, with China the exception at 70 percent). However, if one calculates density as a percentage of the industrialized workforce or wage and salary earners (the OECD uses this basis to calculate union density), these figures are much higher. For instance, although overall Indian union density is somewhere between 2.6 and 6 percent, it is about 38 percent when calculated as a percentage of wage and salary earners and almost 74 percent when calculated as a percentage of formal sector workers (Das 2000). Thus, despite small densities by some measures, the unionized sectors are significant (and often leading edge) parts of the economy.

\section{Forces Driving IR Change}

Most institutional frameworks used for studying IR systems identify forces that drive IR change-for example, both Dunlop (1958) and Kochan, Katz, and McKersie (1986) highlight the importance of the economic, technical, social, political, and legal environments. Although many different forces can cause change in IR systems, we argue that at any given moment, some forces will be more urgent than others. While the movement from 
external influences through process to outcomes may be complicated and difficult for the actors within the system to perceive, the actors nevertheless will attempt to attend to the more salient of the external constraints (if the system is at all functional). This is not to suggest that an IR system should be treated as a single rational actor but rather that particularly urgent external influences will spur action by various different actors (based on their perception of the external influences). For example, it is possible that only one group of actors might respond "strategically" to an external influence, leaving the other actors to react to these actions. Alternatively, it is possible that intended actions often have unintended consequences but that the actors will continue to attempt to address a salient constraint in some manner until it is accommodated adequately (even if through a system "chancing" on a workable set of institutions) or otherwise becomes less salient.

A crucial aspect of the argument is that the most salient constraints facing IR systems throughout the world have shifted over time. However, it is also necessary to note that historically, IR systems have not changed all that much; i.e., there is a tendency for them to get set and remain unchanged for long periods, except for minor modifications (Katz, Kuruvilla, and Turner 1994; Erickson and Kuruvilla 1998a). Yet the last decade has been a period of upheaval in IR systems in the West as well as in Asia, suggesting the possibility that urgent pressure for change has come from the same source. We argue here that there has been change recently in both the most salient constraints and in the overall systems.

Most IR systems in the West and in Asia were institutionalized formally in the decades following World War II [see Kochan, Katz, and McKersie (1986) for the U.S. case and Erickson and Kuruvilla (1995) for several other countries]. In these first decades after the war, most governments and large companies gave priority to maintaining labor peace. For example, note that in the United States the Wagner Act was promulgated to provide a constructive structure for unions to organize in the wake of the sit-down strikes and other incidents of labor unrest during the depression, whereas the Taft-Hartley Act was designed as a counter to the powerful unions and the wave of strikes after World War II. In addition, this phenomenon was not limited to the United States. In Japan's case, for example, there seems to be support for the argument that the basis for the postwar Japanese IR system was the need for the development of strong internal labor markets in Japan in the 1950s, given the problems of strikes and high labor turnover rates (Takahashi 1997; Nakamura and Nitta 1993). In another example, DeSousa (1999) suggests that Indian labor laws were formulated with the explicit purpose of containing industrial conflict: to make it difficult for the parties to go on strike by mandating 
some form of third-party dispute resolution and by attempting to foster "responsible" trade unionism rather than militant trade unionism in both colonial and postcolonial regimes.

There is evidence that the introduction of formal IR rules and regulations in many other Asian nations focused initially on the control of conflict [see Hiers and Arudsothy (1999) for Malaysia, Chew and Chew (1995) for Singapore, and Ofreneo (1994) for the Philippines]. As we will discuss below, industrial peace or stability was seen as a prerequisite for economic development in many of the countries (be it a colonial view of economic development or a nationalist conception of the same). The imperative to control conflict and provide industrial stability in the postcolonial state was critical, given the adoption of industrialization as the engine for economic growth (Kuruvilla and Mundell 1999). In effect, what we are highlighting is the tendency of IR rules and regulations to focus heavily on addressing or reducing conflict at the time of their inception, although we also note that more highly developed nations such as Japan and the United States also emphasized industrial peace in the immediate postwar era. However, we also want to stress that there have been many differences in the ways the various Asian nations sought to attain this goal of industrial peace; i.e., they used differing institutional mechanisms. And it is also true that the goal of maintaining labor peace was influenced strongly by political considerations in some countries. For instance, several authors (e.g., Deyo 1989) have suggested that labor suppression in East Asia was motivated not solely by the need for economic development but as a means of political control to ensure the stability of the ruling regime. ${ }^{3}$

We argue that in Asia as in the West, as product markets became more open to foreign trade, communism weakened, and radical unions and parties declined (for various reasons); labor peace became less of a priority. At the same time, increased product market competition from overseas made cost reduction on the shop floor increasingly important. Such cost reductions often involved increased use of layoffs, temporary workers, and subcontractors. In some nations, cost reductions involved increased skills and labor reallocation within the firm. In other words, the most salient constraint has shifted over time from preservation of industrial peace and stability to the need to maintain and enhance firm-level competitiveness, and this need is driving IR systems throughout the world to focus on creating workplaces that are more flexible in both numerical and functional terms.

\footnotetext{
${ }^{3}$ Deyo (1989) suggests, for example, that in South Korea labor suppression predated rapid industrialization. This argument implies that for the South Korean government (the most powerful actor in South Korean industrial relations), the logic behind the imperative to maintain labor peace primarily was political in nature.
} 
This did not happen overnight. In the West, the relative importance of maintaining economic competitiveness at the firm level (reducing labor costs and increasing productivity) as the most salient constraint gradually grew over the last three decades. The oil shocks, accompanying developments in consumer markets, and the increasing integration of all manner of markets led to the disappearance of rents and thus an increased emphasis on firm-level competitiveness. Some systems adapted smoothly to these changes - for example, the oil shock environment of the 1970s drove several European nations to introduce or strengthen codetermination as a means to improve the ability of firms to react flexibly to changes in the economic environment. For others, however, it took the pressures of the 1980s and 1990s, the increasing internationalization and integration of product and factor markets, and the predictions and perceptions generated by these developments to force the actors to begin seriously addressing the newly salient constraint of reducing unit labor costs and enhancing productivity. The upheavals in Western IR systems in the last decade are an indication of IR regulations and practices being changed in concrete ways to address this newly salient constraint, and in some countries, these changes amounted to fundamental transformation of the systems (Erickson and Kuruvilla 1998a).

We argue that Asian IR systems in the 1990s faced, to some extent, the same pressures. Many Asian nations have experienced continuous and unparalleled economic growth during the last 30 years (the newly industrialized countries) fueled by low-cost export-oriented industrialization strategies. But in the 1990s, given greater internationalization of product and factor markets, some of them are faced with the need to upgrade to higher value-added exports, implying a greater need for functional flexibility, as in Korea and Malaysia. In other cases, Asian nations have responded to the pressures of competition by articulating industrialization strategies that have opened their economies to a greater extent to both foreign direct investment and international trade and are confronted with the need for more functional and numerical flexibility in IR as a part of this transition. For example, in China and India, nations that have liberalized their economies only recently, the pressures to compete in the international marketplace are driving changes in IR to emphasize firmlevel competitiveness. In Korea, democratization and the power of labor unions have forced Korean employers to seek new ways to maintain competitiveness, and this has forced them to change IR strategies. Thus the primary manifestation of the tightening of the firm-level competitiveness constraint can be seen in the search for more functionality and numerical 
flexibility in IR. This is not to say that flexibility was not a concern earlier but more to say that it has become the central concern of IR actors in the 1990s in Asia.

\section{The Concepts of Stability and Flexibility}

It is important to clarify a central part of our argument: use of the terms stability and flexibility and their interrelationship. Stability is used here in its broadest sense, and stability-enhancing actions are interpreted to include the processes of eliminating the causes of industrial conflict, steering conflict away from the modality of strikes to the modality of compulsory third-party dispute resolution, centralized control of wage increases, and in some cases, asserting control over unions and strikes for political purposes. Each nation had a somewhat different conception of stability (as the case discussions below will show). For some actors (e.g., the government in India), stability at the time of institutionalization of the IR system focused on the control of conflict. Consequently, regulations were introduced to ensure that strikes should be withdrawn if either party requested conciliation services from the government. Similarly, the ability of employers to lay off employees was restricted by legislation to eliminate one potential source of conflict. For the government of Singapore, stability was seen as necessary for foreign investment and implied the control of strikes through mechanisms similar to those found in India; but it also implied control over wage bargaining (for nominal wage stability) through the institutional apparatus of the tripartite National Wages Council. Wage stability was seen as key in the early years of economic development. To reduce conflict, transfers, promotions, job assignments, and layoffs were declared "not bargainable subjects" in Singapore. In Singapore and Malaysia, giving the industrial arbitration court the authority to modify collective-bargaining agreements on the grounds that it did not meet the national interest was another method of ensuring some degree of stability (Kuruvilla 1996). In Malaysia, IR stability was linked with political stability, and union federations were not permitted to engage in political action. In more authoritarian regimes such as South Korea, union activity was curtailed severely and the imperative was primarily political rather than economic. Our point is that stability, broadly defined, was a central concern of the dominant actors during the inception of most IR systems in Asia.

Although stability was the most pressing constraint addressed at that time by the actors, we do not argue that these systems were not flexible. In fact, in some of the countries, the institutions that were designed to create 
stability also provided a high degree of functional flexibility in particular. For example, the Singapore case suggests that while the restrictions on bargaining subjects (e.g., transfers, promotions, layoffs, and job assignments) were designed to reduce industrial disputes, they also provided employers with a considerable degree of flexibility in allocating workers. An even more powerful example is that of Japan, where the institutions that provided labor peace in the postwar era also allowed for a great deal of functional flexibility. However, in Singapore and Japan, facilitation of flexibility was not the central imperative driving the development of their IR systems at midcentury; rather, the initial achievement of labor stability provided an environment in which employers were later able to seek functional flexibility. Our argument is that the shift in constraints has created a situation where the imperative to increase various kinds of flexibility has become a central rather than a secondary concern. We now turn to a more in-depth discussion of the concept of flexibility.

Flexibility is also a multidimensional concept. As Grenier, Giles, and Belanger (1997) suggest, it is important to distinguish the institutional. level at which flexibility is examined and the different types of flexibility. Thus flexibility can be examined at the level of the labor market or at the level of the firm or establishment. Flexibility at the level of the labor market refers to those economy-or industry-wide institutions that have undergone change to make the labor market function more effectively. Decentralization in wage bargaining from the industry level to the firm level would be one example of a movement toward this form of flexibility.

In this article we highlight flexibility at the level of the firm or establishment, which focuses heavily on the manner in which internal labor markets are configured to meet organizational needs (Grenier, Giles, and Belanger 1997). There are two primary strategies for achieving this form of flexibility: functional and numerical. They refer to "how" and "how much" labor is used. Functional flexibility strategies refer to those actions which modify existing internal labor markets, e.g., changes in work organization and the work process, investments in training and skills development, tying pay to performance, introducing other forms of flexible pay, and enhancing worker involvement in production decisions, and can include multiskilling, job rotation, work teams, and increases in labor-management collaboration. Numerical flexibility strategies typically involve increased use of casual and temporary labor, subcontracting, layoffs, retrenchments, and other actions that reduce employment security and the number of workers and externalize parts of the production system. Thus a decision to reduce employment and increase subcontracting is an IR system outcome, in our view. Other terms for the two types of flexibility include static (external) and dynamic 
(internal) flexibility. ${ }^{4}$ In this article we will use the terms numerical and functional flexibility.

Because numerical and functional flexibility have different goals (one cuts labor, whereas the other tries to redeploy and motivate labor to be more productive), many have argued that they are incompatible. Yet Streeck (1988) suggests that some numerical flexibility operations such as the creative use of overtime and work sharing can coexist with functional flexibility. Grenier, Giles, and Belanger (1997) suggest that functional and numerical flexibility can coexist in a firm if the workforce is divided into a core group that is the target of functional flexibility strategies and a peripheral group that is the target of numerical flexibility strategies. It is even possible for firms that are already highly flexible internally to begin to focus on external flexibility, as we shall argue is the case in Japan. In general, however, numerical flexibility strategies appear to be followed by the search for functional flexibility, flexibility strategies predominate. Yet there are exceptions, as we note below.

Having defined numerical and functional flexibility, we will use these definitions in our characterizations of how IR systems are changing in the countries in this study. In sum, our hypothesis is that IR actors in the 1980s and 1990s have taken a number of actions to pursue numerical and/or functional flexibility in employment, IR, and human resources (HR) practices and policies as they try to adjust from older sets of salient constraints (the need for labor peace and stability) to the newer constraints (the need for the IR system to promote increasing firm-level competitiveness). Thus, to the extent that there is an underlying cause for the changes reported in the last decade in Asian IR, it is to be found in the general explanation of the shift in the salient constraints. We will attempt to characterize the types of flexibility strategies that predominated during the period of change in a given system.

Note further that we are not arguing that IR systems hinder or enhance the different types of flexibility (they can do either, depending on the nature of the specific practices). Instead, the argument is that the actors (and thus the systems) are now emphasizing numerical and/or functional flexibility as goals and are trying out various methods by which to gain this flexibility. One method toward achieving this is to change some of the institutions,

\footnotetext{
${ }^{4}$ See Grenier, Giles, and Belanger (1997), Streeck (1988), Piore and Sabel (1984), and Deyo (1997) for further discussion on different types of flexibility. Some authors suggest that wage flexibility should be a separate flexibility category, but we see the use of pay as a key component of internal labor markets.

${ }^{5}$ In part, in Asia, we view numerical flexibility strategies as a precursor to functional fiexibility strategies due to the nature of the development of competitive advantage. In general, where competitive advantage is based on low costs, numerical flexibility strategies tend to predominate. Where competitiveness is based on high productivity and skills, functional flexibility strategies predominate.
} 
rules, and practices. These are the major themes we shall investigate in the case studies that follow.

As we write this article, it is important to note that there have been 2 years of severe economic crisis in East and Southeast Asia. In this article we will take into account the short-term reactions of Asian IR systems to this crisis. Our results here are consistent with the view that the short-term reactions are fundamentally in conjunction with longer-term movements (i.e., precrisis) toward increased numerical and functional flexibility in IR and workplace arrangements throughout Asia (Erickson and Kuruvilla 1998b). If anything, the economic crisis has only accelerated movements toward increased numerical and/or functional flexibility and provided a facilitative way out of impasse regarding negotiations over increased numerical flexibility in particular. At the same time, however, the crisis also has spurred new movements toward tripartism and collaborative structures in some of the countries.

In the country cases below, we seek to identify the underlying logic of the IR system when the system was institutionalized, followed by a brief overview of its development and the current state of IR/HR policy and practice. Space limitations permit only a brief description of each case-we do not purport our cases to be comprehensive in their coverage of IR in each country. Rather, we are looking to see if in general, the movements in IR in each country are consistent with our argument. In the section following the case studies we attempt to characterize more broadly the nature of the recent changes in Asian IR systems.

\section{Country Cases}

Japan. There is general agreement that the central features of the Japanese IR system have included workplace-focused enterprise unions, lifetime employment systems, broad-based training, and seniority-based wages. There is also agreement that one of the key outcomes of the Japanese IR system, when examined in conjunction with related Japanese institutions such as the keiretsu system and the system of production organization (subcontracting and quality-focused, team-based work), is the simultaneous achievement of stability in labor market terms and considerable functional flexibility in workplace-level IR through the development of internal labor markets. Our goal here is to briefly review arguments regarding the historical development of the Japanese IR system in the twentieth century 
and then to discuss recent changes and the substantial disagreement over the extent to which the system is fundamentally transforming.

IR policy and practice prior to 1990 s. There is disagreement on the date of institutionalization of the Japanese IR system. Taira (1970) suggests that the lifetime employment practice developed in the late 1800 s in the silk industry, where employers, forced to compete for scarce labor, instituted lifetime employment to create stable employment conditions. The key practices were encouraged by the government, which institutionalized several of them during the interwar period in its Factories Act of 1938. Enterprise unionism emerged after the war based on the structure of the firms (the large employers who accounted for a significant share of employment). Jacoby (1993) and Gordon (1985) also suggest that precursors to the current system could be seen in the company unions of the 1920 s, with institutionalization occurring during the interwar period. Cusumano (1985) argues that it was the early labor-management crises in the postwar period, coupled with the revolution in production management (i.e., the engineering developments under Ohno Taichi), that account for the creation of the more advanced aspects of the internal labor market in Japanese industry, whereas Okayama (1986) also credits the industrial strife of the 1950 s as the most important variable in the development of the Japanese IR system, a view also held by Kenney and Florida (1994) and Takahashi (1997), who argues that "the main stimulus [for lifetime employment] was the experience of large-scale conflict between labor and capital in the early postwar years, partly in response to many workers being made redundant as the war industries shut down. Employers sought a way to end or reduce this conflict. ... [It was] not a social or political norm impervious to pressures of economic change."

Clearly, these authors suggest that the most salient constraint in Japan during this period was the need for labor peace. However, the institutional structures that provided stable internal labor markets also provided Japanese employers with a high degree of functional flexibility in the use of human resources as lifetime employment, firm-specific training, and enterprise-based unionism became widespread. And the interconnections among corporations given the keiretsu structure [cross-corporate holdings and agreements or, as Gerlach (1992) and Berggerren (1993) have termed it, "alliance capitalism"] further enhanced flexibility because workers could be transferred from one company to another when needed within the keiretsu. These connections also made it more possible for firms to sustain their promise of lifetime employment (Berggeren 1993). The development of internal labor markets had an impact on the wider labor market and 
education systems as well, as Nakamura and Nitta (1993) suggest. Nakamura and Nitta note that the development of internal labor markets and lifetime employment systems created a highly segmented labor force with little intersegment mobility. Thus those with lifetime employment invariably were those who graduated from the best schools, and those at lesser schools were forced to enter a different segment of the labor market, from which upward mobility was not possible. This system also made education very competitive as families strove to ensure that their children did well enough to get into the best schools and thus into lifetime jobs. These linkages reinforced the core of the Japanese system well into the early 1980s. Thus the picture that emerges (Table 1) is one characterized by highly functionally flexible IR systems within firms, in a context of a fair degree of rigidity in the labor market more generally. Dore's (1986) term "flexible rigidity" sums up this phenomenon.

It is also true that there were several changes in the Japanese system during the 1970s and 1980s. Notably, there was an erosion of the senioritybased wage concept as increasingly wages began to be tied to skills acquisition and productivity, and employers started the practice of midcareer hires in white-collar and technical occupations. The practice of shukko-transferring employees to other parts of the keiretsu during downturns - had gained in prominence over the last two decades. However, as we shall see in the next section, the changes in the 1990s were even more far-reaching.

Recent changes. Our argument is that in the 1990s there has been an acceleration of changes already underway, as well as changes in other practices that constitute the core of the Japanese system. This has been due

TABLE 1

JAPANESE IR PRE-1990

\begin{tabular}{|c|c|c|c|}
\hline $\begin{array}{l}\text { Union density and } \\
\text { union voice }\end{array}$ & Union structure & Bargaining structure & $\begin{array}{c}\text { Dominant IR and } \\
\text { HR issues }\end{array}$ \\
\hline $\begin{array}{l}\text { Density declined } \\
\text { steadily from approx. } \\
25 \% \text { in } 1970 \text { s to } 18.6 \% \\
\text { in } 1995 \text {. } \\
\text { Unions have had } \\
\text { strong voice at } \\
\text { workplace level } \\
\text { as well as national } \\
\text { level through labor } \\
\text { federations (Rengo). }\end{array}$ & $\begin{array}{l}\text { Largely } \\
\text { enterprise-based, } \\
\text { but each union is } \\
\text { affiliated with major } \\
\text { national labor } \\
\text { federations. }\end{array}$ & $\begin{array}{l}\text { Largely } \\
\text { enterprise-based, } \\
\text { with some informal } \\
\text { coordination on wage } \\
\text { bargaining through } \\
\text { the spring Shunto }\end{array}$ & $\begin{array}{l}\text { Highly developed internal } \\
\text { labor markets at big } \\
\text { firms (with lifetime } \\
\text { employment and firm- } \\
\text { specific training) that } \\
\text { resulted in stability and } \\
\text { functional flexibility, but } \\
\text { some rigidity in external } \\
\text { labor market terms. }\end{array}$ \\
\hline
\end{tabular}


in large part to the effect of the recession of the 1990s, as Berggeren (1993) argues, which has been the deepest one since the war. Thus, in the 1990s, there has been a significant questioning of the lifetime employment concept, with severe declines in job security on an unprecedented scale, changes in hiring practices from schools and universities, a dramatic increase in outsourcing strategies, the introduction of limited-term employment contracts for some occupations, increased wage flexibility, and some degree of union restructuring, along with evidence of the breakup of some keiretsus. By themselves, any one of these changes might suggest a gradual adaptation to new economic circumstances (and indeed, as noted earlier, some of this happened in the 1970s and 1980s), but all of this happening together in the 1990s suggests the critical importance of the recession of the 1990 s in forcing employers to question their existing practices and act to change them. We discuss evidence of these facets of change below.

One facet of change is the decline in job security and lifetime employment, as well as changes in hiring practices. Berggerren (1993) reported the massive declines in capacity utilization, particularly in the automobile and electronics sectors, as Japanese manufacturers located more and more production in Southeast Asia in response to cost pressures. Shimokawa (1998) and Toyonaga (1998) report similar excess capacity problems in the automobile and electrical industries. In the electrical industry, Toyonaga (1998) argues that increased outsourcing of production from Japan (overseas production in this industry increased from 11 percent in 1990 to 16.8 percent in 1996) to other Asian countries has resulted in a net decrease in employment (male employment increased from 1.3 million to 1.4 million, whereas female employment decreased from 1.16 million to 900,000 ).

In these industries, both layoffs and plant closures have occurred (e.g., Nissan's Zama plant, Hitachi's recent layoff of 3000 workers), apart from large job losses for casual/temporary workers and women (traditional buffer groups that sustain the lifetime employment system). In general, there has been an increase in layoffs as a function of downsizing (Yamakawa 1999), and the average tenure in large firms decreased in the 1990-1994 period (Lincoln and Nakata 1997). In 1995, 4.2 jobs were lost per 100 workers, compared with 2.1 jobs per 100 workers in 1991 .

The 1990s have witnessed a sudden and dramatic increase in outsourcing within Japan as well, termed work commissioning. A Ministry of Labor survey (Japan Labor Bulletin 1998) finds that 45 percent of 4500 firms surveyed had increased outsourcing due to the need for increased numerical flexibility. The survey shows two mechanisms of outsourcing. Either the work itself is subcontracted outside the company, or the job is kept within the firm's premises but is done by "dispatched workers" (workers employed 
by a subcontractor providing labor services). In the latter case, regular female employees have been the first to lose their jobs to dispatched workers. The number of dispatched workers has increased from 140,000 in 1985 to 890,000 in 1998 (JLB 2000), whereas part-time workers have increased from 4.7 million to 11.1 million over the same period (JLB 2000).

Apart from the clear evidence of job loss, suggestive of a declining commitment to lifetime employment (Lincoln and Nakata 1997) there are chinks in the hiring system, which is an integral part of lifetime employment. First, there has been a reduction in hiring, and second, there have been changes in the hiring practices of large firms. A recent Ministry of Labor survey (1998) reports that the percentage of graduates hired by large companies fell 17 percent among men and 41 percent among women. The ratio of job openings to job applicants fell to 0.47 (the lowest since 1963). The placement rate for 4-year university graduates was 65.6 percent, the lowest figure since 1951 (at its peak, this rate was 81.3 in 1991). Only 62 percent of high school graduates obtained jobs in 1996, the lowest rate since 1978. Cutbacks in hiring only suggest the extent of the change but do not provide an indication of nature of the changes in the system. Changes in hiring practices by trend-setting firms provide better clues as to whether hiring practices are being transformed.

Siegel (1999) reports that the number of midcareer hires have increased substantially over the last decade and that many companies (e.g., Sony) have started 5-year employment contracts for some occupations, such as software engineers, a clear departure from the system of hiring that was the basis behind lifetime employment. Berggerren (1993) and Lincoln and Nakata (1997) document that several other companies stopped the practice of recruiting graduates from the elite universities in favor of second-tier schools. Moreover, last fall Nissan hired contingent workers for the first time. Two reasons are driving such changes in hiring, suggest Lincoln and Nakata (1997): the cost savings induced by hiring less elite graduates and the fact that fast-changing technologies are undermining the traditional system of taking novices and providing firm-specific skills. For example, the increases in employment in the service sector motivate people to move from manufacturing to services, notably in the finance profession. Thus larger chinks are appearing in the lifetime employment and recruitment system. In what has been seen as an effort to "legitimize" contractual employment, the Japanese Diet passed a new law providing legal backing for limitedduration employment contracts in March of 1998, thus providing a legal basis for the breakup of the lifetime employment norm.

These changes in the employment relationship are set against a wider picture of change in IR and HR in Japan. For instance, there are changes in 
organizational structure toward flatter organizations, eliminating the dual hierarchy system that has existed for decades. Yamakawa (1999) points out changes in corporate governance (reducing the size of the board of directors) allows for quicker decision making: "The competitive and global market has driven Japanese companies to change their management style to make speedy decisions and cut operations costs, including that of human resources" (p. 11). Lincoln and Nakata (1997) document several cases where the determinants of pay have shifted from seniority to performance. While wage increases have been getting smaller, there is ample evidence that the variation in wage increases and bonus payments is increasing, and recently, the National Personnel Authority has recommended pay cuts for government servants to keep in step with the declines in compensation for the private sector (Japan Labor Bulletin 1998). Benson's (1998) longitudinal surveys also suggest an increase in wage flexibility generally.

These changes have reduced the power of trade unions. As Morishima (1999) notes, "Unions in Japan are currently facing a difficult time with increased membership losses and decreasing membership loyalty" (p.11), and Rengo (the predominant peak-level federation) is making efforts to strengthen the industry federations to make up for the weaknesses of enterprise unions by pushing for unification of industrial federations. This is evidenced by the recent merger of Zenkin Rengo (the Japanese Federation of Metal Industry Unions) with Kinzoku Kikai (the Metal Machinery Workers Union of Japan), as well as the establishment of a new union federation in the commercial sector by July 2000 and further, the encouragement of industrial federations in land transportation (a sector that has seen at least 8250 jobs lost in 1999) to merge in 2003.

These changes, we argue, are a consequence of the need for increased numerical flexibility. Observers often have painted the Japanese IR and HR system as being highly functionally flexible, particularly in terms of the ability of Japanese employers to adapt to market conditions. Key elements in this flexibility have been the patterns of subcontracting, the use of temporary labor that enabled the lifetime employment system, highly sophisticated internal labor markets, and the keiretsu system. However, the experience of the 1990s indicates that now different types of flexibility are being sought. As Lincoln and Nakata (1997) note, there is a movement toward a higher level of market-oriented flexibility than the three pillars system has thus far allowed-thus removing the rigid from Dore's term of "flexible rigidities" and hence the focus on numerical flexibility.

We view these changes as a movement toward IR system transformation, given that the evidence suggests changes in most aspects of employment relations in Japan, such as job security, hiring, corporate governance, wages 
and wage flexibility, and the role of seniority (Morishima 1998), as well as union structure, and seemingly would consist of a significant eroding of the three pillars and a move toward a more individual-based system such as in the United States (Brown et al. 1997). There is also some evidence that the keiretsu system is breaking down after the crisis, possibly as a result of firms' capital requirements, and thus one major source of the "stickiness" seems to be weakening. Other observers (e.g., Lincoln and Nakata 1997; Berggeren 1993), however, suggest that there is considerable stickiness still remaining in the Japanese system, and they are hard pressed to decide whether these changes are fundamental. Our view is more similar to that of Benson (1998), who argues that these changes represent an evolutionary process toward more fundamental change that reflects the need for the rigidities in the employment system to be broken down. Although the Japanese IR system witnessed some change in the 1970s and 1980s, the 1990s has seen a major acceleration of change in several different facets of the system, which, taken together, may well represent the beginnings of a radical change in Japanese IR.

South Korea. IR policy and practice prior to 1987. Although there were several changes in Korean IR regulation after the war, the 1953 legislation regarding trade unions and labor disputes formally established IR in Korea. The rights granted to trade unions, however, were revoked during the 1960s and thereafter. During the 1945-1960 period, workplace IR in the major conglomerates known as chaebols (Samsung, Lucky Goldstar, Hyundai, and Daewoo were the largest) was modeled closely on the Japanese system and has been described by various authors as "paternalistic" or "authoritarian" (Lee 1993). Given the chaebos' almost hegemonic hold on industrial activity (their sales amounted to almost 68 percent of gross national product in 1988) and the predominance of small firms (87 percent of establishments have less than 49 employees, accounting for 29 percent of the workforce), clearly the chaebols are the best places to view IR in action (Ungson, Steers, and Park 1997).

Leggett (1997), in reviewing the development of South Korean IR during the 1945-1960 period, sums up its primary characteristics: "the subordination of workers and trade unions to the combined, institutionalized interests of a repressive state and monopolistic capitalism" (p. 67). ${ }^{6}$ The methods different regimes used subordinated labor varied by regime. However, as Kim $(1990,1995)$ and Park and Lee (1993) argue, these

\footnotetext{
${ }^{6}$ Some authors disagree and argue that Leggett's characterization is more descriptive of the 19611981 (Park-chung Hee) and 1981-1987 (Chun-doo Hwan) periods rather than the 1945-1960s period.
} 
methods clearly were introduced to deal with industrial conflict that might threaten the prosperity of the chaebols and thus economic development generally. Apart from direct repression through the use of force, the state also mandated labor-management councils in every enterprise, introduced tripartite commissions at provincial (district) levels to resolve disputes (these commissions grew out of the 1953 legislation), and promulgated laws that restricted direct action by labor through mandated cooling-off periods before $1980 .^{7}$

The ascendancy of a new martial law leader (General Chun-doo Hwan) in 1981 coincided with a change in economic development strategy toward higher-value-added exports (Wilkinson, 1994), and consequently, there were more changes in IR legislation. In early 1981, legal changes mandated the formation of Japanese-style enterprise unions, although the government ensured its system of political control by forcing all enterprise unions to be part of the FKTU (the government-mandated union confederation). Further, given the involvement of both students and church organizations, the government prohibited the involvement of "third parties" in unions. While these actions clearly were politically motivated, they also helped the chaebols contain or avoid industrial conflict and continue their "authoritarian" management styles. Although there were efforts to introduce some labor protection laws and regulate vocational and skills training, the primary focus was political control of IR activity, i.e., stability. Thus the Korean IR system during the period of martial law continued to have dispute prevention and dispute avoidance as the primary focus of its policies as part of the overall goal of maintaining stability in IR for economic development (e.g., in particular, the government's efforts to control wage costs) and political control.

Incidentally, the various restrictions on union activities also provided employers with substantial control over the workplace to pursue the Japanese-style internal labor market arrangements at the workplace level that are characteristic of large Korean chaebols (Kim 1995). The chaebol workplace HR practices were similar to those of Japan, directed as Leggett (1997) argues at achieving a "unified internal labor market," which included implicit employment guarantees, seniority-based wages, and formalized

\footnotetext{
${ }^{7}$ There are two differing views regarding the underlying rationale of IR regulations during the Park period. Deyo (1989) argues that the primary purpose of repressive labor relations during the 1960s was to maintain political stability. Lee (1993) argues that the focus of IR legislation and institutions was altered to be consistent with Korea's export-oriented industrialization strategy and to maintain stability, cost containment, and conflict reduction. Both views have substance and are not mutually exclusive. A regime of repression focused on political stability also can be modified effectively to control costs and enhance an economic development strategy based on low costs within an authoritarian framework.
} 
recruitment from good schools, as well as cultural and ideological programs as part of a strategy to weaken independent trade unions and to promote company-loyal unionism, a point also made by Woo (1997). Not all authors in Korea are convinced that the chaebols were able to pursue an internal labor market-based system to the same extent as the Japanese. Rather, paternalism thrived under an authoritarian framework. Whatever the interpretation, however, power clearly was in favor of the employer during these periods (Woo 1997). Key features of the Korean system before 1987 are depicted in Table 2.

Recent changes. With democratization in 1987, IR legislation and practice have changed substantially, with the Korean IR system entering what Leggett (1997) calls a "transitional period." With liberalization of labor law, the trade union movement mushroomed, with a sharp increase in union density (18.6 percent in 1990) and strikes during the 1987-1989 period (Frenkel and Peetz 1998). The hegemony of the FKTU finally was broken as new, independent unions formed and some of them created the KCTU in opposition to the FKTU (Woo 1997). The scope of bargaining expanded substantially, and trade unions, confronted with a management unused to collective bargaining, have been able to use their economic power to win substantial nominal wage increases (71 percent during 1988-1990) (Park and Lee 1993; Shin and Wailes 1997:3). Bargaining power thus appeared to be with the unions in the years immediately following democratization.

Given the erosion of their competitive position, Korean chaebols have reacted to the militant union demands by following a mixture of suppressive policies (Frenkel and Peetz 1998) and progressive HR practices, although these practices were introduced by only some of the chaebols (e.g., LG promoting labor-management collaboration.). In the early 1990s, employers were pointing out the need to cut labor, given the increases in costs. The

\section{TABLE 2}

SOUTH KOREAN IR PRE-1987

\begin{tabular}{llll}
\hline \hline $\begin{array}{l}\text { Union density and } \\
\text { union voice }\end{array}$ & Union structure & Bargaining structure & \multicolumn{1}{c}{$\begin{array}{c}\text { Dominant IR and } \\
\text { HR issues }\end{array}$} \\
\hline $\begin{array}{l}\text { Union density was } \\
\text { about } 9 \% \text { before 1987, } \\
\text { and union voice at } \\
\text { national and workplace }\end{array}$ & $\begin{array}{l}\text { Unions were } \\
\text { enterprise-based, } \\
\text { with compulsory }\end{array}$ & $\begin{array}{l}\text { Largely } \\
\text { enterprise-based, } \\
\text { but limited form of }\end{array}$ & $\begin{array}{l}\text { Similar to Japan highly } \\
\text { developed internal labor } \\
\text { markets at large chaebol; }\end{array}$ \\
& $\begin{array}{l}\text { single government- } \\
\text { bargaining under } \\
\text { recognized labor } \\
\text { martial law }\end{array}$ & $\begin{array}{l}\text { a general focus on } \\
\text { stability and internal } \\
\text { flexibility. }\end{array}$ \\
\hline
\end{tabular}


state initially tried to inject some wage moderation through the articulation of wage norms (the norm was 10 percent in 1990) with little success as different chaebols adopted different strategies of dealing with the unions. The unions also have been divided during this period. However, some unions, notably those affiliated with the FKTU, advocated moderation given the needs of Korean competitiveness, but the independent unions that started forming around 1991 and finally grew into the KCTU in 1995 (which was illegal and continued to be so until 1999) were not in agreement with the policies of the FKTU.

The erosion in competitive position also saw an increase in Korean investment abroad in low-cost areas, particularly in Asia and Latin America. As Korean exports and profits started to decline during the 1994-1995 period, employers began to step up their demands for IR restructuring to make workplaces more flexible and to get rid of the implicit lifetime employment contract, or norm, that existed in the large chaebols (see Kim and Leggett 1998). The diversity of employer strategies increased as they sought to restructure IR and HR. Although these efforts were met with some degree of resistance by the unions, there was some progress in the movement toward functional flexibility and increasing skills as well as restructuring ([see Pucik and $\operatorname{Lim}$ (1996)] for a review of IR and HR restructuring efforts in one major chaebol).

The government of Kim Young-Sam responded to the growing union militancy in 1996 with a predawn clandestine reform of labor legislation, which on the one hand allowed union participation in politics and allowed multiple unions in the workplace by 2002 and on the other hand avoided recognition of other peak federations until 2000 and, most important, increased the authority of employers to lay off employees (Kim 1997:5). These changes resulted in widespread labor agitation and strikes. In general, the 9 years following democratization can be characterized as a period of experimentation and diversification in IR practice and regulation.

The Asian economic crisis beginning in 1997 hastened the process of IR restructuring. The International Monetary Fund (IMF) bailout of the South Korean economy, coupled with the accession of Kim Dae-Jung (viewed as more friendly to the labor movement than his predecessor) paved the way for far-reaching changes in IR in 1998. For the first time, labor was given participation in national decisions through the creation of the Tripartite Commission, an 11-member commission with 2 representatives from management, the ministers of finance and labor, and representatives from 4 political parties. The commission issued a social pact for dealing with the economic crisis, with several key decisions on IR. These 
included, apart from recognizing the KCTU, the establishment of an unemployment insurance fund ( $\$ 0.3$ billion) coupled with expansion in the amount and periods of unemployment benefits as part of a social safety net package, collective-bargaining rights for the public sector from 1999, the freedom of labor unions to be active politically, a revision of labor laws to permit layoffs, the ability to use temporary labor for periods of up to 1 year, advance notification of intended layoffs, and various obligations of employers in the case of layoffs. In addition, the agreement introduced a change in the long-standing practice of employers paying the wages of fulltime union leaders. As Park (1998) argues, it was the need for numerical flexibility that resulted in these provisions. And Park argues that the labor movement's willingness to accept layoffs could have happened only at this juncture, when the pressure of the economic crisis was great, and with the trust that labor has in President Kim Dae-Jung, although it is not clear that all workers (within the KCTU) supported the agreement.

The effects of the social pact are still being played out. On the one hand, the agreement has met several of labor's long-standing demands, such as recognition of the KCTU as a national federation, collective-bargaining rights for teachers, and more important, a voice in national decision making through the peak-level Tripartite Commission. On the other hand, the economic crisis and the IMF bailout coupled with the law permitting layoffs have weakened workplace unions considerably. This is illustrated by the fact that job security was the primary bargaining issue in 1998 in Korea, whereas it had been taken for granted in the past.

The KCTU, at best a skeptical participant in the Tripartite Commission, thereafter has shown an unwillingness to cooperate in the Tripartite Commission and efforts of the various chaebols to restructure and lay off have been met with a wave of strikes. Although a strike at Hyundai in response to layoffs in 1998 was settled through government intervention, local unions continue to resort to the strike in the face of restructuring efforts by corporations. One consequence since then is several companies have attempted to guarantee some degree of job security (e.g., Daewoo Precision, Inchon Steel, and Korea Telecommunications). Companies and unions are also making attempts to increase labor-management cooperation. For example, the Hanil Lease union used its strike fund of W100 million ( $\$ 82,000$ at current exchange rates) to protect the company from being bankrupted in April 1998. However, it is difficult to determine whether these examples are part of a sustainable trend.

Since the Korean economy has begun its recovery from the financial crisis of 1999, our talks with various Korean scholars (Lee 2000) suggest that the Tripartite Commission has not lived up to its promise of creating a social 
dialogue at the national level. By January 1999, the agreement among the government, employers, and unions via the Tripartite Commission has broken down, primarily over the job security and employment flexibility issues. The workers of the KCTU struck in a campaign to limit employment cuts and replace them with work sharing. By April 24, 2000, automobile workers of Daewoo were on strike protesting the restructuring efforts and potential closure of Daewoo's automotive business, to which the government responded with arrests of striking workers and union leaders. Thus there is considerable turmoil and the new IR system forged in the midst of the economic crisis would appear to be another step in experimentation in South Korean IR in its long-run search for increased flexibility, both functional and numerical. ${ }^{8}$

In summary, then, Korean IR continues to be in a period of transition,. with a lot of experimentation with institutions and a high degree of diversity in practice. The transition to democracy in Korea coincided with, and to some extent hastened, the need for increased flexibility in IR as Korean competitiveness in several sectors eroded, particularly in the lower-cost sectors of textiles, shoes, and electronics, where there has been a migration of Korean firms to the rest of Asia. In other sectors, employers have attempted to restructure their businesses and IR (Frenkel and Peetz, 1998), and the financial crisis has hastened the need for such restructuring. The IMF bailout and the accession of Kim Dae-Jung has facilitated to some degree employers' push for increased flexibility. Despite a peak-level agreement that permitted layoffs, however, the efforts of employers to enhance workplace-level functional and numerical flexibility have been met with resistance by a labor movement that is stronger and more vocal. Further, as a consequence of the 1997 legislation permitting them, the number of industrial unions are growing; between 1998 and 2000, seven industrial unions have formed, and others are in the process of forming although employers have resisted industrial-level bargaining. Clearly, however, numerical flexibility has become a key aim for Korean employers, whereas job security has become a key goal of Korean unions during the decade of the 1990s.

Singapore. IR policy and practice. Singapore's IR system is well known for its distinctive tripartite features and in the view of many observers it is one of the most stable and functionally flexible IR systems in Asia. On adoption of its export-oriented industrialization program, based on foreign

\footnotetext{
${ }^{8}$ The effects of the search for numerical flexibility can be seen in increased earnings inequalities: The Gini coefficient rose from 0.283 in 1997 to 0.320 in 1999.
} 
investment in the 1960s, the focus of IR policy in Singapore was to provide foreign investors with a "stable, cheap, and flexible IR system" (Chiang 1988:239). While low labor costs were clearly its biggest comparative advantage in the 1960s, stability was seen as essential in attracting foreign investment and institutions were devised to create wage stability and industrial peace.

Stability was promoted through the creation of a tripartite I.R structure with joint decision making on all aspects of economic and social development. To create "responsible" unionism, the state provided funding and training to union leaders on economic development issues. To ensure that disputes did not result in strikes, the legislation provided for secret ballots on strikes, a notice period, and withdrawal of strikes once the dispute was under mediation or conciliation proceedings (see Leggett 1993). An industrial arbitration court was established to deal with disputes not settled through mediation and to take cognizance (give legal standing to a collective contract) of all agreements, with the power to refuse to recognize agreements against the national interest (Krislov and Leggett 1985). Strikes were prohibited in industries deemed "essential to the economic development process."

To create stability in wage negotiations, the tripartite National Wages Council recommended standard wage increases throughout the economy (Chew and Chew 1995). At the workplace level, to prevent industrial disputes from arising over certain issues, bargaining was not allowed on transfers, promotions, job assignments, terminations, and hiring. While these laws certainly reduced disputes, they also created the preconditions for all types of flexibility because they gave the employer substantial control over the workplace [see Chiang (1988) and Kuruvilla (1996) for more detailed descriptions of this part of the system]. Strike data suggest that some degree of IR stability has been achieved, in that Singapore reports one of the lowest incidences of strikes in Asia and has seen only one strike in the last 10 years. While the tripartite system clearly provides labor with a high degree of voice over national decision making it is important to point out, as Leggett (1993) does, that it is hard to see the Singapore labor movement as being truly independent of the ruling People's Action Party (Table 3).

Recent changes. Since the 1960s, there have been changes in IR and HR regulations at regular intervals (in 1968, 1972, 1982, and 1984) yet these changes were minor and did not depart from the basic framework. Each change has introduced a little more functional flexibility in IR. In the early 1980s, for example, the need to upgrade Singapore's low-cost-based exportoriented industrialization program to higher-value-added export-oriented 
TABLE 3

SINGAPORE IR

\begin{tabular}{|c|c|c|c|}
\hline $\begin{array}{l}\text { Union density } \\
\text { and union voice }\end{array}$ & Union structure & Bargaining structure & $\begin{array}{c}\text { Dominant IR and } \\
\text { HR issues }\end{array}$ \\
\hline $\begin{array}{l}\text { Union density has } \\
\text { declined gradually from } \\
\text { about } 17 \% \text { in } 1984 \text { to } \\
\text { about } 13.5 \% \text { in } 1995 . \\
\text { Union voice is high } \\
\text { at the national level } \\
\text { through the tripartite } \\
\text { system but low at the } \\
\text { workplace level. }\end{array}$ & $\begin{array}{l}\text { Mix of industrial } \\
\text { and enterprise } \\
\text { unions, although } \\
\text { all new unions } \\
\text { are enterprises } \\
\text { based. }\end{array}$ & $\begin{array}{l}\text { Largely } \\
\text { enterprise-based, } \\
\text { but also to some } \\
\text { degree through } \\
\text { tripartite institutions, } \\
\text { such as the } \\
\text { National Wages } \\
\text { Council. }\end{array}$ & $\begin{array}{l}\text { Focus of policy and } \\
\text { practice on stability } \\
\text { and wage and functional } \\
\text { flexibility; more recently, } \\
\text { a strong focus on skills } \\
\text { development. }\end{array}$ \\
\hline
\end{tabular}

industrialization required more capital-intensive investors, highly skilled labor, and flexible arrangements between the two. The labor movement was restructured; the existing "omnibus" unions were broken up into industrywide unions, and some enterprise unions were created out of existing industry unions and the establishment of enterprise unions in the future was encouraged. This was done to make individual collective-bargaining agreements more sensitive to the economic environments facing individual firms. In support, the National Wages Council desisted from its practice of recommending uniform wage increases and advocated differential increases based on the conditions of industries and firms. To create a more highly skilled workforce, the government restructured education and promoted the skills-development fund (the 1984 legislative change) to encourage firms to invest continuously in skill formation and development (see Kuruvilla and Chua 1999). Over the subsequent years, the National Wages Council further decentralized its wage recommendations, promoting flexible compensation linked to productivity and the use of lump-sum bonuses [see Chew and Chew (1995) for a historical perspective of the evolution of flexible compensation]. Thus, over the years, the Singapore IR system has moved in the direction of greater workplace flexibility under a tripartite framework that guarantees some degree of IR stability.

What has this evolutionary process done to bargaining power? Although the structure is tripartite, thus implying equal voices among all three partners, Deyo (1981), Leggett (1993), and Wilkinson (1994) suggest that the People's Action Party (PAP) has incorporated the labor movement through a combination of strategies over the years, notably, through some degree of repression, legislation, and political incorporation. By the1970s, it became impossible to distinguish between party and labor elites (Rosa 1990). This clearly has continued in the 1990s, for instance, when the head 


\section{4 / Sarosh Kuruvilla ANd Christopher L. Erickson}

of the Economic Development Board moved to become the head of the National Trade Union Congress (NTUC), with which 97 percent of all unions are affiliated. Clearly, then, labor is the "junior partner" in a corporatist framework where government and employers are dominant. However, this status does provide labor with a degree of voice in all forms of national decision making to an extent unmatched in Asia. The degree of voice clearly is influenced heavily by the extent to which the party's and labor's interests are similar; e.g., in dealing with the Asian economic crisis, avoiding retrenchment was a key issue for both labor and the party. At the workplace level, unions are restrained, given the legislative restrictions on bargaining subjects and strikes. Some have argued (Kuruvilla 1996) that Singaporean unions may view that their influence at the national level compensates for their lack of influence at the workplace level. The pursuit of functional flexibility under this framework, to our knowledge, has not made labor any weaker, given the existing institutional structure and despite the gradual decline in trade union membership as a function of structural changes in the economy.

Much of the focus of government policy and institutions in recent years has been on increasing skills development and training in Singapore through various legislative and institutional mechanisms (Kuruvilla and Chua 1999). In response to the economic crisis, although no formal rules have changed, the tripartite partners have chosen to emphasize retraining, reskilling, and HR development more generally in an effort to improve the employment prospects for displaced workers. The type of flexibility followed by Singaporean firms tends to be functional flexibility rather than numerical flexibility.

Malaysia. IR policy and practice prior to 1985 . The IR institutions of the colonial period played a critical role in developing Malaysia's postindependence (1957) IR system (Hiers and Arudsothy 1999). The primary focus of colonial labor policy in Malaysia was the elimination of communist (and presumptively militant) unions and the establishment of compliant and "responsible" unions (Sharma 1996). These objectives were met through the office of the Registrar of Trade Unions, which had wide powers to accord or not accord registration to unions (Sharma 1996:67), and through mandating occupation-based unions. Postindependence IR policy built on this foundation of control over union formation but put in additional elements to meet the goal of stability in IR for economic development and regime maintenance. Therefore, although union federations were allowed, they were incorporated as societies, not trade unions. These federations were not allowed to be politically active. Hiers and Arudsothy (1999) argue that these 
policies were designed to ensure that unions would not present a threat to the ruling coalition government.

On the bargaining front as well, IR policy was geared both to ensure continued investment and to contain strikes for economic development. For example, employees had the right to strike, but this right was circumscribed by a series of administrative rules, strikes should be stopped once conciliation or mediation proceedings commenced. At the level of the workplace, bargaining on job assignments, promotions, transfers, and layoff and retrenchment decisions were not allowed by the legislation, thus ensuring that disputes regarding these subjects would not result in conflict. Further, all collective agreements had to be recognized (given legal standing) by the Industrial Arbitration Court, which could refuse to recognize agreements that were inimical to national economic development interests. Several authors (e.g., Arudsothy and Littler 1993; Kuruvilla and Arudsothy 1995) highlight the importance of IR stability via effective conflict management as the key basis for these workplace IR regulations and legislation.

The principle of supremacy of economic development goals over unfettered trade union rights continued through Malaysia's phase of import-substitution industrialization until the middle 1970s and deepened with the adoption of low-cost labor-intensive export-oriented industrialization predicated on foreign investment, primarily in the electronics sector. Kuruvilla (1996) documents an increase in government oversight and intervention in IR in terms of union formation, dispute settlement, and various initiatives to keep labor costs low. ${ }^{9}$ There is consensus in the literature that the demands of the export-oriented strategy and the need to continually attract foreign investment were the prime motivations for the government's repressive IR policy (see Frenkel and Peetz 1998).

IR and HR practices of employers and firms also reflected this low-cost focus. Foreign employers often refused to recognize unions, intimidated union activists, or inserted anti-union clauses in individual employment contracts (Ariffin 1997). Further, commitment-oriented management practices, deployed in combination with favorable compensation, reduced the perceived need for unionization (Frenkel and Peetz 1998). The growth of

\footnotetext{
${ }^{9}$ These included changing the way overtime was to be calculated and changes in overtime rates and refusal to enact minimum-wage legislation and equal-work pay legislation. There also was a decisive effort to ensure that unionization would not occur in the export-oriented electronics industry, the mainstay of Malaysia's EOI strategy (e.g., banning unions in the electronics sector, increased state intervention in union recognition and dispute resolution). For a more detailed description of the various government initiatives to control unions during this phase, see Kuruvilla and Arudsothy (1995) and Grace (1990).
} 
TABLE 4

UnION MALAYSIAN IR

\begin{tabular}{|c|c|c|c|}
\hline $\begin{array}{l}\text { Union density and } \\
\text { union voice }\end{array}$ & Union structure & Bargaining structure & $\begin{array}{c}\text { Dominant IR and } \\
\text { HR issues }\end{array}$ \\
\hline $\begin{array}{l}\text { Union density has } \\
\text { declined gradually } \\
\text { from about } 13.5 \% \\
\text { in } 1986 \text { to about } \\
11.7 \% \text { in } 1995 . \\
\text { Union voice at both } \\
\text { national and } \\
\text { workplace levels is low } \\
\text { given various restrictions } \\
\text { on union formation } \\
\text { and bargaining. }\end{array}$ & $\begin{array}{l}\text { Largely } \\
\text { enterprise-based, } \\
\text { although industrial } \\
\text { unions are allowed } \\
\text { in some industries } \\
\text { such as banking } \\
\text { and plantations. }\end{array}$ & $\begin{array}{l}\text { Largely } \\
\text { enterprise-based, } \\
\text { except in some } \\
\text { industries such as } \\
\text { banking; in some } \\
\text { industries, enterprise } \\
\text { unions cannot be } \\
\text { affiliated with } \\
\text { industrial unions } \\
\text { (e.g., electronics). }\end{array}$ & $\begin{array}{l}\text { An environment of } \\
\text { extremely tight labor } \\
\text { markets and headlong } \\
\text { growth in electronics } \\
\text { has driven a shift away } \\
\text { from a low-cost focused } \\
\text { IR regime to a more } \\
\text { skills development } \\
\text { focused HR system } \\
\text { and is reflected in both } \\
\text { policy and practice. }\end{array}$ \\
\hline
\end{tabular}

contract work as employers searched for increased numerical flexibility and the employment of guest workers, both documented and undocumented, further reduced union power and influence (Table 4).

Recent changes. By the late 1980s, further changes in IR became apparent. Competition from other low-cost producers forced Malaysia to adopt a more technology-intensive export strategy. And in order to attract more technology-intensive investment, the focus of the state's IR policy turned to one of skills development rather than cost containment and union suppression. Government policies now focus on providing employers with incentives to invest in training, with the introduction of the Skills Development System, and reforming the education sector to ensure the continuous supply of skilled workers for industrial needs. Signifying this shift in the basis of IR and HR policy, the Ministry of Labour was renamed the Ministry of Human Resource Development (Arudsothy and Littler 1993).

Foreign multinationals that dominate employment in the export sector, they account for over 50 percent of manufactured exports, have introduced new forms of work organization and progressive HR practices, many of which require greater worker involvement but in a nonunion setting (Kuruvilla 1996). Therefore, the gradual evolution to a high-skill and "positive" HR policy system is underway in a nonunion environment. ${ }^{10}$

There has been great interest in performance-based pay in Malaysia, given the concern that productivity growth is slower than wage growth.

\footnotetext{
${ }^{10}$ Kuruvilla (1996) documents in detail the new forms of HR management systems in the electronics industry (Malaysia's largest export industry and its largest employer) and several studies by Rajah and colleagues also describe this shift (see Salih, Rajah, and Young 1988).
} 
A tripartite accord in 1996 sought to expand the use of performance-based pay, which is currently practiced in only 1 or 2 percent of Malaysian firms. Recent (1998) legislative changes to the definition of the wage were designed to increase incentives among employers to adopt performance-based pay schemes.

In general, the move toward highly flexible IR and HR practices can be discerned in Malaysia, similar to the path taken by Singapore. The Asian economic crisis has further intensified the drive to restructure IR and HR practices to enhance both functional and numerical flexibility. During the economic crisis, firms restructured their businesses to a considerable extent and focused on reducing the labor force, introducing labor-saving technology, and preparing for a more skill-intensive workforce (Peetz and Todd 2000). However, unlike in Singapore, Malaysian unions do not have any institutional bulwarks against major membership losses. Union density has been low in Malaysia, and the labor movement has not had a significant voice at either national or local levels (Kuruvilla 1996). Peetz and Todd (2000) note that union membership declined by 1 percent (from 11 to 10 percent) during the economic crisis. Curiously, one consequence of the economic crisis has been the introduction of tripartism for the first time, although it is a limited form; the tripartite committee monitors retrenchment and encourages firms to pursue alternatives to retrenchment. It is not clear whether this form of tripartism will remain once the crisis is over; Peetz and Todd (2000) argue that this is an important question for future research on Malaysia.

The Philippines. IR policy and practice prior to the 1980s. There is evidence to suggest that industrial peace was the driving focus of Philippine IR policy at its inception. The Court of Industrial Relations (CIR), established in 1936, was created primarily to handle labor disputes and Ramos (1981) argues that the CIR's primary function was "to contain the growth and militancy of the labor movement" (p. 443). The immediate postwar era saw a rise in industrial disputes during a period of reconstruction under an import-substitution industrialization (ISI) program. The ISI program lasted until the 1960s and during this phase the Philippines witnessed its fastest growth, an average of 11 percent per year.

To deal with the rising number of industrial disputes, the state initially put in place a system of bilateral collective bargaining, based largely on the Wagner Act in the United States. The act itself was called the Industrial Peace Act of 1953, clearly signifying the underlying logic of the IR system: to promote industrial peace. In fact, the preamble to the law clearly states its aim "to eliminate the causes of industrial unrest" (Ramos 1981:451). 
Thus a U.S.-style system of collective bargaining was introduced and this lasted until the declaration of martial law in 1972. From less than 50 collective-bargaining contracts in 1953, the number increased to 852 contracts in 1972. This was accompanied by various pieces of labor and social welfare legislation, in particular minimum-wage legislation. Over the years, however, the minimum wage set the standard for wage negotiations in different areas; consequently, the wage-setting process became tripartite as employers, unions, and the government bargained over the minimum wage to be set. Clearly, however, the focus of IR was the preservation of labor peace.

Martial law in 1972 changed the nature of IR drastically. Intensification of the country's export-oriented industrialization program in the $1970 \mathrm{~s}$ brought with it several changes in IR policy (Villegas 1988; Macaraya and Ofreneo 1993). First, there was the focus on suppressing labor and on keeping costs low. This was achieved by banning strikes and introducing compulsory arbitration to guarantee foreign investors industrial peace (Villegas 1988). Various provisions, including the power of the Secretary of Labor to issue injunctions against strikes, weakened the ability of labor to push through their demands in several industries. Second, to maintain stability, the highly fragmented and decentralized unions were restructured along industrial union lines and all trade unions were required to be affiliated with the government-controlled Trade Union Congress of the Philippines (Kuruvilla 1996; Villegas 1988; Ofreneo 1994). Third, various labor laws and standards were revised downward to continue to attract foreign investors to capitalize on the Philippines competitive advantage of low labor costs.

Although the more restrictive aspects of the Marcos regime were lifted with the ascendancy of Corazon Aquino in 1986, Philippine IR policy continued its low-cost focus, with several restrictions on the ability of unions to strike. In essence, the underlying logic of IR regulation, which had been to create a U.S.-style level playing field, underwent a change during the export-orientation regime toward emphasizing low-costs and tilting the balance heavily in favor of employers (Kuruvilla 1996) (Table 5).

Recent changes. When we examine firm-level policies during the $1990 \mathrm{~s}$, it is clear that firms were focusing heavily on "flexibilizing" IR further, given the competition from China and Vietnam in low-cost assembly operations that were the mainstay of the Philippines' export-oriented industrialization program. Numerical flexibility appears to be the key term here. In a wideranging article on globalization's impact, Barranco-Fernando (1994-1995) documents the trends in practices. Two of the most pervasive forms of 
TABLE 5

PHILIPPINES IR

\begin{tabular}{|c|c|c|c|}
\hline $\begin{array}{l}\text { Union density and } \\
\text { union voice }\end{array}$ & Union structure & Bargaining structure & $\begin{array}{l}\text { IR and } \\
\text { HR issues }\end{array}$ \\
\hline $\begin{array}{l}\text { Although union density } \\
\text { figures suggest } 11 \% \\
\text { unionization, less } \\
\text { than } 600,000 \text { workers } \\
\text { are covered under } \\
\text { collective-bargaining } \\
\text { contracts. } \\
\text { Union voice is low } \\
\text { at workplace level and } \\
\text { at national level. }\end{array}$ & $\begin{array}{l}\text { Highly fragmented } \\
\text { labor movement, } \\
\text { with over } 5000 \text { unions, } \\
150 \text { federations and } \\
\text { labor centers, } \\
\text { organized on many } \\
\text { different enterprise, } \\
\text { industrial, regional, } \\
\text { and occupational } \\
\text { lines. }\end{array}$ & $\begin{array}{l}\text { Limited } \\
\text { enterprise-based } \\
\text { collective bargaining } \\
\text { in large firms and } \\
\text { public sector, with } \\
\text { tripartite negotiations } \\
\text { on minimum wage } \\
\text { fixation. }\end{array}$ & $\begin{array}{l}\text { Union avoidance } \\
\text { policies, particularly } \\
\text { in foreign-dominated } \\
\text { export oriented } \\
\text { electronics sector, } \\
\text { coupled with union } \\
\text { suppression during } \\
\text { martial law years. }\end{array}$ \\
\hline
\end{tabular}

employment flexibility include subcontracting and labor-only subcontracting. Under this system, workers are engaged on short-term contracts via a labor service contractor such that, they cannot be made permanent (the labor rules define permanent worker as one who works in continuous employment for more than 6 months). While Barranco-Fernando documents the large increases in outsourcing and labor-only contracting, a recent survey by the Bureau of Employment and Labor Statistics suggests that in manufacturing roughly 25 percent of the jobs are done by laborservice contractors.

The "casualization" of what were permanent jobs also was accompanied by an increasing anti-union stance taken by employers (see Ofreneo and Ortiz 1998). This movement clearly weakened trade unionism at both national and workplace levels. Collective-bargaining coverage declined from 621,000 in 1993 to 540,000 in 1998 (note that the number of union members was 3.6 million in 1998). And there is anecdotal evidence that the large-scale retrenchments and subcontracting resulted in losses of trade union members (Kuruvilla et al. 2000). Further, in the last election, none of the candidates supported by labor won their seats in congress.

The Asian economic crisis clearly has accelerated these trends. In a more recent investigation of the effects of the crisis on IR, case studies of 16 firms in diverse industries (Kuruvilla et al. 2000) suggest dramatic efforts to reduce head count, increased subcontracting, and a restructuring of IR in view of increasing low-cost competition from China and Vietnam. Clearly, there is a focus on the workplace that is driving change in Philippine IR. And the crisis has forced the Philippines to accelerate the move toward numerical flexibility driven by the need to cut costs in conjunction with an economic development strategy that is still based on the competitive advantage of low costs. 
It is against the weakness of the trade union movement that the efforts at tripartism during the economic crisis must be evaluated. The aims of tripartism are to help alleviate the effects of the crisis but also to promote numerical flexibility at the same time. The tripartite social accord signed in February 1998 eased restrictions on layoffs to promote economic restructuring while improving social protection through the expansion of social security. The social accord also encouraged firms to use layoffs as a last resort and to explore alternatives to layoffs. The Philippines also has seen the increased use of labor-management councils (rather like works councils, but with a more limited mandate), introduced by employers with government encouragement but with limited union acceptance (Erickson et al. 2000). While it is too early to evaluate the effect of these councils on labormanagement cooperation, this remains an interesting question for future research.

India. IR policy and practice prior to 1991. In his wide-ranging examination of the colonial origins of Indian IR policy, DeSousa (1999) highlights how the Indian government built on colonial labor institutions and regulations to fashion an IR system that sought to control industrial conflict through a plethora of protective labor legislation, influenced by the strong ties between the major political parties and labor forged in the struggle for independence.

Under this regime, many aspects of workplace IR and HR were regulated, including detailed laws on safety and health, leave, dismissal, and layoffs, so as to avoid sources of conflict [see DeSousa (1999) for a detailed historical evolution of Indian labor law]. The Industrial Disputes Act mandated that employers could lay off workers only temporarily, 180 days with compensation, and provided that employers must seek government permission, rarely given in view of the close ties between labor and political parties, which was for retrenchment and even closure of factories. The method of dispute settlement also reflects the underlying purpose of this act: ensuring that conflict did not undermine economic development. Thus, although the right to strike existed, it could be exercised only after due notice and the strike had to be stopped when either party requested third-party intervention through government conciliation officers. If conciliation failed, the government had the power to refer the dispute to compulsory arbitration or to a labor court or industrial tribunal, depending on the nature of the dispute, for final decision. Thus laws regarding labor standards, protection of employees against unfair dismissal, and retrenchment and closure, in theory, would reduce the potential sources of conflict, and should conflict arise, the dispute-settlement mechanism would be able to contain and 
resolve it. In addition, given the absence of social security legislation, and in view of the government's goals to protect employment, the costs of social policy such as retirement (e.g., the Provident Fund Act of 1952), medical care, and to a certain extent child care (the Indian Factories Act of 1948 mandates child care facilities in large factories) were thrust on the employer.

This worker-centered IR policy was sustained to a large extent by the country's ISI strategy, which emphasized the growth and long-term development of heavy capital goods industries in the public sector with largely indigenous technology (Sodhi 1993), coupled with a policy of industrial licensing, import controls, and restrictions on foreign ownership that protected both public- and private-sector firms from international competition. Therefore, as long as ISI was in place, the higher costs and the relative lack of flexibility imposed by the IR regulations did not pose a serious problem because Indian manufacturers did not have to compete in the international market (Hiers and Kuruvilla 2000). The protectionism afforded to manufacturers also resulted in the growth of inefficient firms (Venkataratnam 1993). In IR terms, these inefficiencies were reflected in excess employment in public sector industries such as power and in the private sector in an inability to negotiate the introduction of labor-saving new technology or rationalization and labor cost-control strategies that involved workforce reduction, along with a high incidence of strikes. Further, the absence of sole-bargaining-agent legislation created a multiplicity of unions at each workplace; unions competed with each other for membership in a given workplace, resulting in highly conflictridden IR because the conditions for a stable partnership between employers and unions did not exist (see Ramaswamy 1983; Venkitaratnam, 1993).

Thus, although the initial goal of labor policy was to provide workers with a high degree of protection and ensure some degree of stability in terms of both employment for workers and conflict avoidance, collaborative labor-management relations did not emerge. It should be noted, however, that there was more diversity in IR regulation than the picture painted earlier-largely because the different states in India enact their own IR laws and also because of differing institutional histories in different states. For example, trade unions in Mumbai (Bombay) historically have been quite different in their orientation toward collective bargaining relative to trade unions in Calcutta or other parts of India. Besides regional differences, there are also institutional differences across industries (Table 6).

Recent changes. In 1991, Indian economic policy witnessed a dramatic turn with the dismantling of the 40-year-old ISI program and the adoption 
TABLE 6

INDIAN IR PRE-1991

\begin{tabular}{|c|c|c|c|}
\hline $\begin{array}{l}\text { Union density and } \\
\text { union voice }\end{array}$ & Union structure & Bargaining structure & IR and HR issues \\
\hline $\begin{array}{l}\text { Union density at } 2-6 \% \\
\text { as a percentage of } \\
\text { the nonagricultural } \\
\text { workforce but about } \\
38 \% \text { as a percentage } \\
\text { of formal sector } \\
\text { workers. } \\
\text { Union voice high } \\
\text { given symbiotic ties } \\
\text { between unions and } \\
\text { political parties at } \\
\text { national level and high } \\
\text { at workplace level given } \\
\text { strong legislative support } \\
\text { for unions; unions also } \\
\text { had "positional"power } \\
\text { given higher density } \\
\text { rates in specific industries. }\end{array}$ & $\begin{array}{l}\text { Unions structured } \\
\text { on enterprise, } \\
\text { industrial, political, } \\
\text { and regional lines; } \\
\text { all major political } \\
\text { parties have trade } \\
\text { union arm, and } \\
\text { many trade unions } \\
\text { headed by } \\
\text { politicians; no sole } \\
\text { bargaining agent } \\
\text { legislation, resulting } \\
\text { in considerable } \\
\text { inter-union rivalry. }\end{array}$ & $\begin{array}{l}\text { A mixture of industrial } \\
\text { and enterprise } \\
\text { bargaining; although } \\
\text { legislation provides } \\
\text { for tripartite } \\
\text { structures and works } \\
\text { council-type } \\
\text { institutions, in } \\
\text { practice none } \\
\text { followed. }\end{array}$ & $\begin{array}{l}\text { Highly conflictual } \\
\text { labor relations given } \\
\text { the intense inter-union } \\
\text { rivalry; growth of } \\
\text { inefficient practices } \\
\text { as public-sector } \\
\text { firms and some } \\
\text { private-sector } \\
\text { firms were shielded } \\
\text { from competition. }\end{array}$ \\
\hline
\end{tabular}

of a liberalized open economy. ${ }^{11}$ The effects of such a major change in economic policy after 45 years of ISI have been dramatic. Overnight, Indian businesses have been threatened by international competition that they are not prepared to face. These pressures have resulted in major debates regarding IR policy and have brought about a shift in the relative power of business and labor. IR legislation reform is on the agenda, given the pressure from both employers and the World Bank to allow an "exit policy" (to allow employers to retrench workers or close industries) (Mathur 1993). A tripartite committee formed for this purpose has recommended the creation of a safety net for retraining of retrenched workers and for

\footnotetext{
${ }^{11}$ Venkataratnam (1993), Sodhi (1993), and Mathur (1993) highlight the changes. These include the following: Licensing of industries was largely removed, the rules regarding monopoly restrictions were relaxed, restrictions on the ceiling on foreign investment were removed, and the public sector was opened to privatization. Free entry and exit of firms in all industries (except a few strategic ones) are now allowed. In addition to these reforms, trade policy was revamped to promote exports and free trade, the Indian currency was made fully convertible (free floating), and the restrictions on imports of several goods were liberalized. Fiscal policy was amended to reduce the fiscal deficit, control the underground economy (estimated to be one-fifth the size of the economy), and reduce subsidies to agricultural products, and several price controls were removed. Financial markets were liberalized, banking regulations were reformed, and stock markets were freed up from government control.
} 
retrenchment compensation, although the legislation has not been changed to date (Mathur 1993; Hiers and Kuruvilla 2000).

Moreover, IR practices are also undergoing change. One significant outcome of structural adjustment and liberalization has been the employer push for workforce reduction. Given the inability to retrench, employers have introduced voluntary retirement schemes (VRSs) to shed excess labor. Although precise estimates of the number of people on VRSs are not available, Venkataratnam (1993) projected that a total of 5 million jobs will be lost through VRSs in the public sector. As of end 1997, about 1 million public-sector employees had utilized VRSs. Hiers and Kuruvilla (2000) also note the increased importance of numerical and functional flexibility in employer strategies in the private sector in particular.

Employer practices are more aggressive than previously demonstrated. The number of lockouts has increased dramatically, even as strikes have declined (Venkataratnam 1993). In addition, in order to avoid unionization, employers are promoting workers into administrative and supervisory ranks to take them outside the purview of the Industrial Disputes Act (Venkataratnam 1993). There are also increased efforts of employers to invest in joint consultation for productivity improvement. Venkataratnam suggests that for the first time employers feel that the government is on their side and that this has brought about what many call "employer militancy," with collectivebargaining contracts showing an ascendancy of management rights.

The beginning of a government-business coalition, in contrast to the previous government-labor coalition, is increasingly apparent. The traditional link between unions and political parties (each major political party has its trade union arm) provides the labor movement with considerable voice despite the low density figures. The government-labor coalition has weakened considerably given the state's enthusiastic support for economic liberalization and labor's opposition to it. In the state of Maharashtra, for the first time the government has declared several private-sector firms as "essential and public utilities," permitting a ban on strikes in these sectors (Hiers and Kuruvilla 2000). In addition, Mathur (1993) suggests an increased incidence of union avoidance policies by employers.

Clearly, the IR system is exhibiting tensions as it attempts to break with the rigid existing policies and practices. The need to compete both domestically and globally with the best in the world has forced Indian employers to strive for increased numerical flexibility, and this has been manifested in the need to reduce head count, restructure IR, attempt labor-management collaboration, and in some cases avoid unions. Hiers and Kuruvilla (2000), in a wideranging survey of Indian industry in 1997 (16 firms in 5 industries), provide numerous examples of the movement toward numerical flexibility and a clear 
increase in greenfield nonunion plants. Another recent study covering 300 collective-bargaining agreements in the Indian private sector found that one in two included provisions for greater numerical flexibility and closer cooperation in the labor-management relationship (Venkataratnam 1997). In addition, although the legislation has yet to be changed, the firm-level strategies emphasize numerical flexibility more than anything else.

In essence, these practices have accentuated the diversity existing in Indian IR systems considerably. Bhattacherjee (2001) suggests that there is so much variation in the Indian IR scenario that it is no longer appropriate to think of one "national" Indian IR system. Overall, the evidence clearly suggests a shift away from maintaining labor peace as a key underlying imperative of the IR system and towards the enhancement of firm-level competitiveness through increases in numerical flexibility as India becomes more integrated into the world economy.

China. IR policy and practice prior to 1980 s. China's IR system must be understood in terms of its economic and political organization. Although the All-China Federation of Trade Unions (ACFTU) was set up as early as 1925, its incorporation into the Chinese communist party (O'Leary 1994) defined the labor movement's role within a state-dominated ISI policy in a centrally planned closed economy. The trade union constitution's preamble states the role of the union rather clearly: "The Trade Unions of China are the mass organization of the working class led by the party and are the transmission belts between the party and the masses" (Littler and Lockett 1983). Therefore, although the unions played a variety of economic and political roles, the role of transmission belt (communication between the party and workers) was the most central (Littler and Lockett 1983).

The transmission belt ostensibly contributed to the development of the state's industrial, employment, and welfare goals. The main characteristics of the system included state ownership of industrial enterprises, the implicit guarantee of employment for workers, an administrated allocation of labor irrespective of the price mechanism [see Jackson (1994)] for an elaborating, centralized state planning of production and distribution, centralized wage setting and HR policy determination, a rigid labor market with little interenterprise or interregional mobility, and the absence of price- or efficiency-driven controls over industry. Although the emphasis varied over time, the broad industrial policy that followed was a mixture of heavy industrialization in the core sectors of the economy coupled with both import-substitution industries and small-scale industrialization to promote economic growth in the rural sector (Chiu and Frenkel 2000). 
The administrative bureaucracy at central and regional levels governed industry, whereas the party and the trade unions developed parallel bureaucracies. In IR terms, however, the workplace specifically, the work unit the Danwei, was most important (Warner 1987; Han and Morishima 1992). At the Danwei level, employment was lifelong and beyond-retirement meant that the employee's children were encouraged to take the employee's place (Jackson 1994) -and the enterprise was responsible for the provision of housing and all welfare, medical, and retirement benefits, as well as for social and entertainment needs. Thus the enterprise shouldered many of the responsibilities that are the province of national social security in other nations. Warner (1987) suggests that the Danwei provided a sense of identity for the industrial worker based on cradle-to-grave welfare benefits. The term iron rice bowl is used to describe this inclusive IR system (Jackson 1994). Note, also, the often-heard quotation that the Chinese industrial enterprise was not organized to make profits but to fulfill the economic and social policy of the state.

Within this system, IR consisted of a dualistic structure of co-determination. Warner (1987) provides an analysis of IR in the Chinese factory, which we summarize here. The trade union focused on day-to-day shop floor problems but walked a fine line between its responsibilities of educating the workers, ensuring success of the enterprise, and ensuring that management of the enterprise did not exploit workers. The union dealt with matters such as grievances and decisions regarding social activities. Workers' congresses composed of representatives of workers, met about four times a year and had responsibility for strategic issues, such as the scrutiny of plans and budgets, decisions on enterprise funds for welfare activities, changes in organizational structure and payment systems, and election of the enterprise director and other key management personnel. Thus the workers' congresses made key decisions that trade unions carried out on a regular basis (although there was considerable variation in the degree to which workers' congresses were involved in decision making). The glue that held this together was the presence of party members in each enterprise, who often were responsible, through their presence in trade unions; workers' congresses, and management, for all important decisions.

The combination of administrative labor allocation and the iron rice bowl produced a rigid and inflexible system within the enterprise and outside as well. The absence of numerical flexibility via allocation and recruitment policies was further reinforced by the absence of labor mobility given the household registration system, which only permitted workers to be employed permanently in their area of residence. This has been cited as the "greatest institutional barrier to free labor mobility" (Jackson 1994). 
Thus the objectives of IR policy was in some sense to support the economic and social structure that communism built-in other words, mobilization of the mass of workers behind economic policies. Note, however, that there were numerous differences under different regimes and across different industries in how workers' congresses and trade unions operated (Jackson and Littler 1991). For instance, trade union rights and roles were banned during the cultural revolution (restored under the modernization period of Deng) and there was some degree of loosening in IR as Deng sought to give enterprises greater control over their management after 1978 [see Jackson (1994) for a more extensive description of liberalization during this period]. By and large, however, the need for flexibility in the IR system was absent, given the absence of competitive pressures in the system (Table 7).

Recent changes. The Chinese IR system has been in considerable ferment since the opening up of the Chinese economy after 1978 and in particular after 1983. There is a lot of research on the change in economic development strategy, and we will not revisit that research here (e.g., Becker and Gao 1989; Chan 1995). However, the change in economic policy brought about a greater decentralization in the state-owned enterprises (SOEs), which were allowed to manage themselves more independently, and an increase in the number of foreign-investment enterprises (FIEs), foreignowned joint-venture firms in export, and special economic zones all over the country. Decentralization in the state sector implied changes in IR and HR practices, with new practices that are increasingly focused on getting a higher degree of numerical and functional flexibility. Jackson (1994), for instance, documents the early progress in instituting numerical flexibility by introducing the contract system to replace the lifetime employment system and the "flexibilization" of wages. The joint ventures brought with them flexible IR and HR practices from abroad. Further, as part of these reforms, the Chinese government enacted a new labor law in 1994 that essentially

TABLE 7

CHINESE IR PRE-1980s

\begin{tabular}{|c|c|c|c|}
\hline $\begin{array}{l}\text { Union density and } \\
\text { voice }\end{array}$ & Union structure & Bargaining structure & IR issues \\
\hline $\begin{array}{l}\text { State-sponsored } \\
\text { unionism with density } \\
\text { about } 70 \% \text {. } \\
\text { Unions had a strong } \\
\text { voice with respect to } \\
\text { labor welfare policies } \\
\text { in workplaces. }\end{array}$ & $\begin{array}{l}\text { Based on the } \\
\text { structure of the } \\
\text { state administrative } \\
\text { units. }\end{array}$ & $\begin{array}{l}\text { Highly centralized } \\
\text { rules regarding wages } \\
\text { and } \mathrm{HR} \text {, but localized } \\
\text { bargaining over other } \\
\text { aspects. }\end{array}$ & $\begin{array}{l}\text { The iron rice } \\
\text { bowl system in } \\
\text { state-owned } \\
\text { enterprises, highly } \\
\text { rigid HR and } \\
\text { IR practices. }\end{array}$ \\
\hline
\end{tabular}


sought to create a new IR system within the socialist market economy, but implementation of this law has not been uniform (Chiu and Frenkel 2000).

In terms of IR legislation, the government's focus in the foreigninvestment sector is to keep basic labor protection and welfare laws as similar as possible to the state-owned sector (Chan, Li, and Sculli 1989). Thus, in joint-venture firms (although there are differences in rules across economic zones and provinces), there are detailed rules regarding IR and HR practices. There is a ceiling regarding wage payment currently set at 150 percent of state-sector wages and, in effect, a legislated system regarding employee benefits that parallels the state-provided benefits at the Danwei. Every enterprise must have a union, which can attend the board meetings of the companies and which gets a company-supported office, 2 percent of the wage bill, and the salaries of union reps are paid by the company. The purposes of unions here are the same, to ensure the success of the enterprise, while there is also a strong emphasis on ensuring that workers do not get exploited and that their basic rights are protected. ${ }^{12}$

However, workplace IR and HR practices in the FIE sector show considerable variety, often affected by country of origin. Thus Western multinationals have a very different reputation as employers than Korean and Taiwanese companies (Chiu and Frenkel 2000). Variation is facilitated by weak and haphazard enforcement of labor legislation. Wage setting (subject to the minimums and the stipulated ceiling of 150 percent) is determined by the enterprise. On average, in 1995, wages in the FIE sector were about 1.45 times the wages in the state-owned sector (Chiu and Frenkel 2000). Other employment practices are completely within the discretion of the employer, subject to the basic standards legislation. Despite the ACFTU directive to organize every workplace, only 36 percent of workplaces have been organized so far, with the labor movement showing little ability, or interest, in speeding up the organization rate, and as several observers have noted, it has few resources with which to do so. Most important, there is little evidence of guaranteed lifetime employment in this sector, beyond the possibility of renewal of short-term contracts. Employment contracts are short term, highly specific, impose restrictions on their employees, and can be changed unilaterally by the employer, and in several cases, no contracts are signed at all [Chiu and Frenkel, 2000; for example, they note that in Xiamen (Fujian Province), over 90 percent of FIEs have not provided employment contracts].

\footnotetext{
${ }^{12}$ For a more detailed description of FIE IR and HR management, see Chan, Li, and Sculli (1989), O'Leary (1998), and Chan (1998). However, also see Seung (2000) for the latest rules here.
} 
There is increased variation in IR within the state-owned sector as well (O'Leary 1998). There has been pressure to restructure IR and HR practices in this sector to increase productivity, upgrade skills, restructure work practices, and increase numerical flexibility (Han and Morishima 1992; Chan 1995). Despite regulations to limit management autonomy to lay off workers, there have been widespread violations leading to increasing unemployment and worker protests (Lee 2000). In some large state enterprises that have restructured, IR and HR practices emphasize productivity and numerical flexibility, with wages tied to performance, extensive use of contract labor, and massive retrenchment; for example, Baoshan Steelworks reduced its workforce from 40,000 to 17,000 in 10 years (Freund 1998). There is a much greater variance in earnings, especially within industries, based on the different economic circumstances of firms. In other smaller state-owned enterprises that recently have been bought by foreign concerns, notably in the low-cost labor-intensive manufacturing sector dominated by investors from Hong Kong and Taiwan (this sector is most responsible for China's astounding export performance in the 1990s), IR and HR management is characterized by low wages, refusal to follow minimum-wage laws, blatant violation of labor law provisions, high rates of wildcat strikes and labor disputes, and very little job security (AMRC 1998). Lee (2000) documents that in these sectors, changes in IR and HR emphasizing numerical flexibility have taken a heavy toll on the workers. ${ }^{13}$ Chan (1998) suggests that the employment system in the state sector is clearly in transition and has already shifted away from the state-oriented system, but the key challenge is in the method of adjustment to the market economy and the considerable variation in the ability of different SOE managements to adapt.

The labor movement in China has been slow to adapt to these changes. On the one hand, the numerical flexibility-enhancing strategies followed by SOEs have hindered union membership. In addition, decentralization of decision making down to the enterprise level has not been matched by adequate autonomy for unions or the right to strike. On the other hand, although there is state support for the extension of collective bargaining, the ACFTU has been very slow to organize, as we have already seen. Chan (1998) notes that the labor movement has limited funds and limited organizers and tends to view new organization as a bureaucratic exercise. In the FIE sector, many labor regulations are not enforced given that provincial governments believe that enforcing such laws may drive off

${ }^{13}$ Detailed reviews of the changes in practices also can be found in Child (1995). 
foreign investment (Chan and Senser 1997:107). Thus the power of the labor movement has been weakened by the changes (Seung 2000).

The net effect of the changes in economic policy and labor law has been an increase in the diversity of IR and HR practices in China and diversity within state enterprises and between SOEs and FIEs. In effect, there is a clear transition from centralized IR and a highly welfarist (iron rice bowl) and rigid system to a more profit-driven, flexibility-oriented IR and HR system [see Han and Morishima (1992) for a discussion of specific changes]. There is tremendous variation in IR reform and differential progress across industries and sectors, but the trend is fairly clear: The focus is on increased numerical, functional, and wage flexibility.

What is less well known is the nature of IR and HR in the rapidly expanding nonforeign, private sector of the Chinese economy, especially in large firms. Zhao and Nichols (1998:97) convey the degree of experimentation rather well in their textile industry study: "The managements' labor control strategies owe something to long-established cultural forms; they owe something to a more recent socialist practice and ideology; and they owe something to a mixture of practices in the capitalist world." This suggests that it is still too early to discern any degree of "system stability." However, all the evidence taken together indicates that the most salient constraint facing IR in China has shifted to the need to enhance enterprise competitiveness.

\section{Discussion}

These cases permit us to draw several conclusions. First, it is clear that in most of these countries, the initial primary goal of the IR system was to maintain labor peace and, more generally, industrial stability. The stated rationale for the need for stability varied from nation to nation. For example, in India and the Philippines, the rationale was to channel conflict away from strikes to third-party dispute-settlement mechanisms given that strikes were seen to hinder economic development. In Singapore, industrial conflict was seen as a deterrent to foreign investment, whereas in Malaysia and South Korea, there were apparent political imperatives for IR stability. Note, also, that in many countries the IR system began to be institutionalized only in the postwar period, coinciding with independence for some of the countries. Table 8 indicates the dates of institutionalization of the IR systems in this sample, and shows approximate dates of the recent changes. And, similar to the experience of the advanced industrial nations in other regions (Katz, Kuruvilla, and Turner, 1994; Erickson and Kuruvilla, 1998a), 
TABLE 8

ChANGES IN IR SySTEMS

\begin{tabular}{lcc}
\hline \hline Country & $\begin{array}{c}\text { Institutionalization } \\
\text { of old system }\end{array}$ & System change \\
\hline Japan & $1930 \mathrm{~s}$ & $1990 \mathrm{~s}$ \\
South Korea & 1945 & 1987 \\
Singapore & 1965 & \\
Malaysia & $1960 \mathrm{~s}$ & $1980 \mathrm{~s}$ \\
Philippines & 1945 & $1980 \mathrm{~s}$ \\
India & 1947 & 1991 \\
China & 1949 & 1985 \\
\hline
\end{tabular}

NOTE: The choice of dates for the institutionalization of the old system is controversial, as noted in the text. We have focused on independence, when several significant new laws in many of these countries were enacted. But industrial relations existed in these countries even before independence, under colonialism in India, Malaysia, Singapore, and the Philippines and under Japanese occupation in South Korea. In addition, our choice of the 1950s for the institutionalization of the Japanese system rests primarily on the development of the practices of lifetime employment and the highly developed internal labor markets in Japanese companies. Yet these practices built on the pre-war Japanese IR system.

the IR systems of these countries experienced long periods of stability before the dramatic and in some cases fundamental changes of the $1980 \mathrm{~s}$ and $1990 \mathrm{~s}$, as Table 8 indicates $^{14}$.

It is also clear that there have been major changes in the industrial relations systems of these countries in the last decades. Table 9 provides a simple listing of the changes in IR, suggesting that, similar to the experience of the advanced industrial nations, the 1990s have been a time of ferment in Asian IR systems as well. In addition, as Table 9 suggests, what has changed in IR varies across the countries. In some countries the changes in IR and HR can be seen in legislative changes, but often change is manifested in the strategies of the parties. Irrespective of what has changed (and we do not have a common definition of what must happen for a change to occur), the cases clearly suggest that many of the changes in each nation have been

\footnotetext{
${ }^{14}$ In making the above argument, we have implicitly treated the institutionalization of industrial relations in many of these countries as being co-terminus with their independence. Yet, industrial relations regulation and legislation existed in these countries before their independence. And, in most cases, the colonial era legislation was the basis for the post-colonial legislation, and many of the postcolonial industrial relations institutions in these countries built on colonial institutions. Previous work that has examined the impact of colonialism on industrial relations systems of developing countries (as in three of the countries in this paper) makes the argument that the purpose of colonial industrial relations was for Singapore, Malaysia, and India, to encourage the growth of responsible unionism and to limit industrial conflict, and both of these goals were also the goals of the post-colonial state (Kuruvilla and Mundell, 1999). Yet, independence allowed these states to make autonomous changes in their IR systems, even if the changes were not major, and hence we treat the date of institutionalization to be the same as the date of independence.
} 
TABLE 9

NATURE OF IR SYSTEM ChANGE

\begin{tabular}{|c|c|c|c|c|c|c|c|}
\hline \multirow[b]{2}{*}{ Country } & \multicolumn{3}{|c|}{ Change in structures ${ }^{a}$} & \multicolumn{2}{|c|}{ Change in strategies ${ }^{\mathrm{a}}$} & \multirow{2}{*}{$\begin{array}{l}\text { Change in } \\
\text { legislation }\end{array}$} & \multirow{2}{*}{$\begin{array}{l}\text { Change in } \\
\text { government } \\
\text { involvement }\end{array}$} \\
\hline & Un & Er & $\mathrm{Bg}$ & Un & $\mathrm{Er}$ & & \\
\hline Japan & $\mathrm{N}$ & $\mathrm{N}$ & $N$ & $\mathrm{~N}$ & $\mathrm{Y}$ & $\mathrm{N}$ & $\mathrm{N}$ \\
\hline South Korea & $\mathrm{Y}$ & $\mathrm{Y}$ & $\mathrm{Y}$ & $\mathrm{Y}$ & $\mathrm{Y}$ & $\mathrm{Y}$ & $\mathrm{Y}$ \\
\hline Singapore & Y & $\mathrm{N}$ & $\mathrm{Y}$ & $\mathrm{N}$ & $\mathrm{Y}$ & $\mathrm{Y}$ & $\mathrm{Y}$ \\
\hline Malaysia & $\mathrm{Y}$ & $\mathrm{N}$ & $\mathrm{Y}$ & $\mathrm{N}$ & $\mathrm{Y}$ & $\mathrm{Y}$ & $\mathrm{Y}$ \\
\hline Philippines & $\mathrm{Y}$ & $\mathrm{N}$ & $\mathrm{N}$ & $\mathrm{Y}$ & $\mathrm{N}$ & $\mathrm{Y}$ & $\mathrm{Y}$ \\
\hline India & $N$ & $\mathrm{~N}$ & UD & $\mathrm{Y}$ & $\mathrm{Y}$ & UD & UD \\
\hline China & $\mathrm{Y}$ & $\mathrm{Y}$ & $\mathrm{Y}$ & $\mathrm{Y}$ & $\mathrm{Y}$ & $\mathrm{Y}$ & $\mathrm{Y}$ \\
\hline
\end{tabular}

${ }^{\mathrm{a}} \mathrm{Un}=$ union; $\mathrm{Er}=$ employer; $\mathrm{Bg}=$ bargaining; $\mathrm{Y}=$ yes; $\mathrm{N}=\mathrm{no} ; \mathrm{UD}=$ undetermined.

nontrivial. Moreover, the similarity in timing with the changes in Western IR systems hints strongly at the underlying common cause of increased competitive pressures due to an integrating world economy.

Consistent with our argument, the cases suggest that the most salient constraint facing Asian IR in the 1990s is the need for enhanced firm-level competitiveness through increased numerical and functional flexibility. The causes of the need for numerical and/or functional flexibility varied across the nations. In the Indian and Chinese cases, this was due to liberalization of the economies to integrate with the global economy. For example, in India, the changes in the IR system can be linked directly to economic liberalization, the need to be more competitive when integrated into the global economy, an argument that is also true of the Chinese case. In Singapore, Malaysia, and the Philippines, which have been more open to the global economy than India and China (by the traditional measures of trade as a percentage of gross domestic product and foreign direct investment as a percentage of gross domestic product), the reliance on key industries that are critically affected by changes in world demand (semiconductors, electronics assembly) has driven a continuous movement toward greater numerical and functional flexibility in IR to maintain firmlevel competitiveness. In South Korea, democratization and the increased militancy of trade unions hastened the erosion of South Korea's competitive advantages in a range of industries such that employers began the push for IR adjustment in late 1980s. In Japan, competitive pressures in several industries, notably automobiles and electronic components, resulted in a shift of production outside Japan in the late 1980s, and the recession in the economy thereafter created pressures for changes in long-established patterns of IR. Further, in most countries, the recent economic crisis has 
only accelerated these movements for change in IR particularly in Japan, the Philippines, South Korea, and Malaysia. Despite the varying causal factors, in every single country in this study, restructuring and IR and HR changes started to occur in the late 1980s and 1990s. As the cases suggest, there is little doubt that the changes in IR and HR policy and practice appear to be driven by the need of firms to be more flexible, in either numerical or functional terms, in order to be more competitive.

Notably, even in the cases where the Asian financial crisis has seen an upsurge in tripartite arrangements (Malaysia, South Korea, and the Philippines) or where the crisis has played a watershed role in the design of new IR systems (South Korea), these arrangements also have stressed numerical flexibility (see Erickson and Kuruvilla 1998b). As noted earlier, we want to stress that our emphasis on the imperative to enhance numerical and functional flexibility as a result of shifts in the salient constraints is necessarily a generalization that requires some qualification. Clearly, the particular institutional structure that provided labor peace and industrial stability in Japan was well suited to the development of functional flexibility, and this type of flexibility spread to some other Asian nations as well (most notably South Korea) under the old systems through imitation and under the influence of Japanese multinationals. We contrast this case with the United States, where the institutions of job-control unionism maintained labor peace while allowing for a great deal of numerical but minimal functional flexibility through use of the layoff-recall system. The shift in constraints has led to an increased emphasis on numerical flexibility in most of the countries, whether or not a particular system started from a high level of functional flexibility, although Singapore and Malaysia at least have also taken actions to increase functional flexibility during the system change. The difference, we argue, is that the need for flexibility is now a primary concern rather than an institutional side effect of the need to maintain labor peace and stability. The nature of flexibility (numerical or functional) under the old systems and the primary "flexibilization" emphases under the new systems are depicted in Table 10.

We have argued that the most salient constraint in the 1990s has been the need to enhance firm-level competitiveness by increasing both numerical and, in some cases, functional flexibility. An alternative explanation is that it is not a shift in constraints that we are seeing but rather a reassertion of employer control. This argument suggests that the reassertion of employer control may have been brought about by the following: Increased competitive pressures weakened labor's ability to achieve its aims through strikes, strikes are decreasing in Asia, and hence, stability is not of any great concern anymore. With weaker labor, employers are able to assert 
TABLE 10

Flexibility Strategies

\begin{tabular}{|c|c|c|c|c|}
\hline \multirow[b]{2}{*}{ Country } & \multicolumn{2}{|c|}{ Old system } & \multicolumn{2}{|c|}{ New system } \\
\hline & Numerical & Functional & Numerical & Functional \\
\hline Japan & & $\sqrt{ }$ & + & \\
\hline South Korea & & $\sqrt{ }$ & + & + \\
\hline Singapore & & $\sqrt{ }$ & & + \\
\hline Malaysia & & & + & + \\
\hline Philippines & & & + & \\
\hline India & & & + & \\
\hline China & & & + & + \\
\hline
\end{tabular}

NOTE: See text and Table 8 for dates of institutionalization of old system and for dates of system change. A $\sqrt{ }$ under a type of flexibility in the old system means that the given type of flexibility existed to a significant extent in the country before the system change. $\mathrm{A}+$ under a type of flexibility in the new system means that the given type of flexibility is being increased as part of the system change. Blank spaces in both columns basically indicate that a system was rigid.

themselves and increase their bargaining power. There is much to support this argument--lower strike rates and considerable evidence that enhanced competitive pressures have weakened labor. However, Asian labor, with some exceptions, has never been particularly strong, and in most countries, employers always have had greater bargaining power. We see these cases as suggesting that given the need for increased numerical flexibility in particular, actions by employers and some governments have caused labor to be even weaker than before.

Characterizing the Change. The direction of change. All the cases suggest a movement toward increased numerical and/or functional flexibility in IR, and in this respect, these nations evidence similarities with the advanced industrial world. In Asia, however, the search for flexibility has not necessarily been coterminal with decentralization in collective bargaining, as in Europe and North America (noted by Katz, 1993). This is largely because most Asian IR systems have never had a history of centralized bargaining. Rather, the locus of bargaining always has tended more toward the workplace level. In the few cases where industry-wide bargaining dominated (e.g., in the banking sectors in India and Malaysia), the locus of bargaining gradually is evidencing some shift to the enterprise level in the 1990s (Peetz and Todd 2000; Hiers and Kuruvilla 2000). In China, where the wages of the state sector were highly centralized prior to 1984 , there have since been several sets of changes leading to decentralization of wage setting, with enterprises given more power to decide on their own wages (China and Vietnam were notable exceptions to the otherwise decentralized systems in 


\section{4 / Sarosh Kuruvilla and Christopher L. Erickson}

Asia). Otherwise, however, movement toward decentralization is not a common phenomenon given the decentralized workplace model that previously characterized Asian IR systems.

In fact, there is even evidence of some degree of recentralization in Asia, with the introduction of tripartite arrangements (in South Korea, the Philippines, and Malaysia) consequent to the Asian economic crisis. However, it is too early to make a decisive call on whether these tripartite mechanisms are here to stay. In the Korean situation, tripartism has occurred as part of a package of far-reaching changes in the Korean IR system, but in the Malaysian and Philippine cases, tripartism appears to be more of a reaction to the high degree of job loss caused by the economic crisis. However, one of the foci of recent tripartite arrangements has been negotiations to increase functional flexibility, apart from encouraging employers to use layoffs only as a last resort.

Approaches to flexibility. Although there is a general movement toward greater flexibility in IR, the nature of the flexibility being sought varies across sectors, industries, and countries. Given the wide variation in the types of industries and firms operating in each country, it is logical to expect the existence of different types of flexibility within each nation, but it is also possible to examine which form of flexibility predominates in a given nation. In India and the Philippines, a movement toward the numerical type of flexibility appears to predominate. "Casualization" and subcontracting are predominant in the Philippines, whereas voluntary retirement schemes and greenfield strategies are predominant in India; union avoidance and suppression strategies have increased in both countries. In this regard, India exhibits a much greater variation than the Philippines.

Functional flexibility strategies appear to predominate in Singapore and Malaysia. Prior to the crisis, these two countries tended to evidence movement toward an aggressive and new form of HR management that included wage "flexibilization," changes in work organization, upskilling, and changes in work processes. In Malaysia, for example, in the electronics industry there has been a movement toward the recruitment of higherskilled labor that can participate in the newer production processes, with much higher wages and the provision of job security and other benefits, but in a nonunion environment. Its tight labor markets are also a source of pressure for functional flexibility and skill improvement in Malaysia.

Our analysis suggests that China is experiencing increased external labor market flexibility and at the firm level has been witnessing increases in both functional and numerical flexibility ever since deregulation of the economy. In South Korea as well, both numerical and functional flexibility are being 
enhanced at the level of the firm. Previously, South Korean companies had attempted to restructure to achieve more functional flexibility given the increases in labor costs in the 1987-1991 period, but some also adopted numerical flexibility strategies such as the movement of production out of the country to lower-cost regions. The financial crisis has driven a more urgent imperative for flexibility of both types.

The nature of IR change in Japan has focused almost exclusively on the reduction of head count during the 1990s. This focus on numerical flexibility has been realized through greater use of subcontracting, increases in the ratio of temporary to permanent workers, increased voluntary retirements, higher incidences of interfirm transfers, lower hiring levels, and some changes in the commitment to lifetime employment. However, we note that the changes relate to "how much" (and for how long) labor is employed, not "how" labor is used; i.e., the focus on numerical flexibility comes over and above the large extent of functional flexibility for which the Japanese IR system is famous and reflects the breakdown of the more rigid aspects of the system.

What influenced the choice of different flexibility strategies in these nations, particularly before the crisis? Although our cases do not suggest a definitive answer to this question, we can identify four interrelated factors that appear to be associated with the choice of flexibility strategies. First, there appears to be some evidence that the greater the extent of institutional arrangements in states that have placed a high emphasis on job security in the past, the greater is the proclivity to use numerical flexibility strategies as an initial step. This seems to have been true even where the ability to lay off or retrench employees remained constrained. For example, the Indian IR system is an example of extreme rigidity before economic liberalization, and that rigidity, particularly in terms of the inability to lay off or retrench, was seen as a barrier to effective restructuring to meet the newly emerging international competition after liberalization. Given this, the use of voluntary retirement schemes and the adoption of greenfield strategies predominated (Hiers and Kuruvilla 2000). The Japanese system as well, was functionally flexible within the firm but extremely rigid in general labor market terms, and the recession, excess capacity, the movement of factories to Southeast Asia, and growth of the service sector have exerted their pressures for change. Numerical flexibility approaches were seen as initial adjustments. Thus, whether or not there has been some form of functional flexibility in the past, numerical approaches appear to be more likely where there has been a previous strong emphasis on job security.

A second factor driving the adoption of different flexibility strategies pertains to the source of competitive advantage of different nations and 


\section{$216 /$ Sarosh Kuruvilla and Christopher L. Erickson}

firms. Deyo (1997) argued that numerical flexibility strategies will tend to predominate in firms in exceptionally competitive product niches. Both lowand high-cost product niches exist. Our own view is that numerical flexibility strategies tend to dominate in countries and industries where the source of competitive advantage is low labor costs. Some support for this argument can be seen in the case of the export industries of the Philippines, notably in garments and shoes, and similar low-cost industries in India. In firms and nations that seek to capitalize on low costs, there is little incentive to invest in long-term training and continuous upskilling, associated with functional flexibility. The Philippines' continued focus on low costs thus led to an emphasis on numerical flexibility strategies despite the absence of a particularly rigid IR system.

A third factor associated with the choice of flexibility is the existence of governance institutions that encourage long-term investments in technology, research and development (R\&D), and HR development. Deyo (1997), for example, argues that functional flexibility generally is found in states that underwrite a supportive social infrastructure in training, education, and $\mathrm{R} \& \mathrm{D}$, where labor standards are enforced, and where the state provides incentives to invest in training and organizational development. The governments of Singapore, South Korea, and more recently, Malaysia have provided the conditions for functional flexibility in many respects. Singapore, South Korea, and Malaysia all have reformed education systems, have ensured the supply of skilled personnel for industry, and have created incentives for training and upskilling via skills-development funds (in Malaysia and Singapore) and tax incentives (in South Korea). In addition, all these governments have funded massive infrastructure projects necessary for competing in a global economy. In contrast, both the Philippines and India suffer from an infrastructure shortage that hinders development, and to a large extent, governments in these two nations have not created institutions that will promote the growth of functional flexibility.

Unions, the fourth factor, also play a role in influencing this kind of flexibility strategy, although the extent of functional flexibility and union strength does not seem to be related in a predictable manner across the countries in our sample. It is reasonable to expect that strong unions will push firms and countries in the direction of functional flexibility strategies. It is true that stronger unions in South Korea have affected, and continue to influence, the ability of Korean chaebols to adopt numerical flexibility strategies before the economic crisis despite the obvious need of the chaebols to cut labor costs. Firm-level evidence in South Korea and more recently in some firms in the Philippines tends to suggest support for this notion; i.e., negotiations regarding head count have been attempted in several firms 
since the early 1990 s with little success. It was only after the onset of the economic crisis and the consequent erosion in union bargaining power that numerical flexibility strategies were adopted. In Japan, it could be argued that unions were strong in the 1960s and 1970s, which encouraged the growth of functional flexibility, but over the 1990s, their declining strength appears to coincide with a focus on numerical flexibility strategies. Note also, however, that functional flexibility strategies sometimes have appeared where unions are weaker (Singapore and Malaysia), whereas numerical flexibility strategies have been adopted where unions are stronger (Japan and India). Thus the precise way in which unions influence the choice of flexibility strategies is not obvious (at least at the national level of analysis) and perhaps requires a more detailed historical analysis in each nation. There is evidence, however, in studies of industries and firms that unions have had an impact on decisions regarding flexibility. Recently, to counter the effects of numerical flexibility, unions in many countries have made attempts to merge to try to centralize bargaining arrangements (e.g., Korea, Philippines), although these efforts are tentative. Further, there is little in the way of transnational bargaining that might counter the numerical flexibility strategies of employers.

As noted earlier, all these factors impinge on the type of overall flexibility strategy undertaken, and their relative importance varies across countries, industries, and firms. Moreover, although we have discussed these four factors separately, it is important to note that they tend to work in conjunction.

Change versus transformation. Clearly, there have been changes in Asian IR systems. We have argued that the most salient constraint facing the actors in the systems has changed from the need to maintain labor peace and industrial stability to the need to enhance firm-level competitiveness by promoting numerical and functional flexibility. The key question that we wish to address here is whether these changes amount to a "transformation" underway in Asian IR systems. Note that similar changes in the advanced industrial nations have led authors to argue for the existence of fundamental transformations in IR, a topic that is debated hotly. Since the changes in IR in many countries in Asia appear to be driven by some of the same factors as in the advanced industrialized nations outside the region (i.e., reduced rents due to increased competition), it is relevant to ask the question here as well.

We use a recent article on the nature of IR transformation by Erickson and Kuruvilla (1998a) to interpret the changes in Asian IR. According to their framework, the key element in deciding whether a transformation has occurred is whether there has there been a serious reconsideration by the 


\section{$218 /$ Sarosh Kuruvilla ANd Christopher L. ERICKSON}

key actors of the deep structure of the IR system: the network of fundamental, interdependent choices that determines the basic configuration into which the system's units are organized. Any change that does not involve a change in deep structure cannot be labeled transformation. Applying this schema to these country cases, we find the following: Three of the systems have adapted to meet newly salient constraints without significant changes in underlying deep structure (Singapore, Malaysia, and the Philippines), whereas two others show tentative evidence of transformation (India and Japan) and two others show more unambiguoús evidence of transformation (South Korea and China).

For instance, in the case of South Korea, a wide range of evidence suggests that a transformation is underway. After democratization, there was a reconsideration of IR policy and a rise in militant unionism and wage levels, but the government's response, on the one hand, encouraged the growth of new unions and, on the other hand, continued suppressive policies by refusing to recognize alternative trade union federations. During the period 1987-1995, the government attempted in various ways to structure bargaining, without much success, and employers and unions began a process of either dealing with each other or experiencing higher levels of industrial conflict. Then the onset of the economic crisis brought about conditions for a major change in IR. We argue that the formation of a tripartite IR system, coupled with recognition of alternative federations, granting of bargaining rights for public-sector workers, and legitimization of layoffs through changes in the law, suggests a change in the deep structure of the South Korean system. The fundamental change in South Korean IR from a deep structure viewpoint is this: For years, the Korean IR system was heavily controlled by the government with the explicit purpose of putting economic development over labor rights with minimal voice accorded to labor. The system that has just been put in place is radically different, in that labor is a partner in the process, bilaterism in IR is a given, and the focus on rights is paramount. Yet there are indications that the new deal will not hold because unions and employers recently have opted out of the Tripartite Commission. This suggests continued experimentation as the actors in the system seek to develop a new, stable deep structure.

As far as the Chinese system is concerned, it is relatively easy to make a judgment in favor of transformation. There appears to be a reconsideration of the deep structure of IR in the state system in China: As many observers have noted, there has been an abrupt departure from the iron rice bowl to a more market-oriented IR system. Transformation in IR is linked to economic, political, and social transformation as well (Jackson 1994). 
So, too, there is some evidence of transformation in the Indian and Japanese cases, although the evidence is more ambiguous here than in the previous two cases. In the case of India, the changes in economic development strategy in the 1990s have brought about rapid changes in IR practice. For the first time, employers are on the offensive, unions have lost their political power as their traditional political partners (the political parties) have been pro-liberalization in direct opposition to the unions' position, and the range of IR outcomes has varied considerably compared with the past. Today, the interests of the industrial employer appear to be more important to the government than before. There have been several revolutionary changes in labor law at the state level, although central government labor laws have not yet been changed; these are being debated at the moment. Arguably, the shift in some of the basic beliefs about IR (i.e., from a belief in a very high degree of protection for workers, safeguarded from layoffs or retrenchment, based on strong union-political party ties in an import-substitution regime, to a much more market-based set of assumptions) suggests the beginnings of reconsideration of the deep structure of Indian IR.

In Japan, the changes in the economy, coupled with the new law that permits short-term employment contracts, coupled with various new approaches of firms with respect to lifetime employment practices, are suggestive of the beginnings of change in the deep structure of the Japanese system. One could argue that the predominance of numerical flexibility strategies in a country with very flexible internal labor markets, which had become entrenched over time through supporting and reinforcing practices and insulated from the wider labor market, is evidence that the carefully constructed Japanese employment system is breaking up. There is change in almost every established feature of Japanese employment and IR practice and institutions, with intensified change in the 1990s. In fact, in the years 2000 and 2001, a significant number of major Japanese corporations announced layoffs. Such a breakup might suggest a reconsideration of the deep structure reflected in the three pillars, although the new set of basic underlying assumptions is difficult to discern at this point. ${ }^{15}$

In contrast, the IR systems of Singapore, Malaysia, and the Philippines show much less evidence of transformation, as per Erickson and Kuruvilla's (1998) definition. Certainly they have changed in some respects, but there

\footnotetext{
${ }^{15}$ We note as well that in terms of the Erickson and Kuruvilla (1998a) framework, all four of these possible "transformations" (South Korea, China, India, and Japan) are of the discontinuous type. All these nations have experienced change that is rapid relative to the past and with great deal of experimentation with new structures.
} 
has been little evidence of reconsideration of the deep structure underlying the systems. The changes can be classified as more adaptive and are all consistent with the imperative of numerical and/or functional flexibility. There have been changes in what institutions do as well as firm practices.

In Singapore, the assumptions underlying the system have remained the same: that IR arrangements primarily should enhance economic development through the preservation of both stability and functional flexibility, that the best way of achieving this is to create tripartite institutions that provide unions with voice at the national policymaking level but restrict their influence at the workplace level, and that IR and HR institutions must adapt and change continuously in deference to economic development goals. Although the basic beliefs underlying Singapore's IR system have not changed, the various IR and HR institutions often have adapted to meet changing economic needs. For example, when it became clear that nationaland industry-level bargaining posed a threat to firms whose different economic circumstances mandated differential wage levels and increases the structure of trade unions was changed in the early 1980s: enterprise unions were mandated. Similarly, while the tripartite National Wages Council (NWC) in the 1960s sought to promote uniform wage increases to maintain Singapore's economic competitiveness as a low-wage manufacturing center, with the imperative of functional flexibility in the 1980s and 1990s, the NWC now promotes flexible pay strategies for different industries and firms and takes the lead in disseminating information about pay linked to productivity. Yet there is little evidence of reconsideration of deep structure.

In Malaysia, as Hiers and Arudsothy (1999) have suggested, the deep structure of the system is premised on a government-business collaboration that has sought to systematically exclude labor from the decisionmaking process at the national level and to facilitate both numerical and functional flexibility by limiting labor voice through a number of different mechanisms. This formed the basis for the government's highly interventionist IR strategy during the period of export-oriented industrialization and its later strategy of encouraging functional flexibility through the creation of new institutions for skills development while attempting to ensure that the electronics sector remained nonunion. The one significant change in Malaysia is the emphasis on tripartism during the Asian economic crisis, which may be suggestive of the beginnings of a reconsideration of the existing deep structure based on governmentemployer autarchy. However, it appears to this point that tripartism has very limited objectives: to alleviate unemployment, to promote functional flexibility, and to restrain social unrest in the wake of economic restructuring. 
In the Philippines, the basic underlying concept of a pluralistic IR system has remained essentially unchanged, although it was suspended temporarily under the Marcos regime. The pluralistic system has resulted in weak and politically oriented unions through the historical development of a highly fragmented labor movement that continues to this day. Over the years, the low-cost export-oriented industrialization strategy and a huge labor surplus have weakened unions to a considerable extent, and the new electronics industry is largely nonunion. The post-Marcos era thus has seen a return to a pluralistic and democratic yet highly fragmented IR system, with employers in large sectors of the economy mostly free to pursue nonunion strategies with little interference, much as in the United States. The emphasis on tripartism during the Asian economic crisis has been, as in the Malaysian case, highly limited to date. Thus we argue that minimal reconsideration of deep structure has occurred in Singapore, Malaysia, and the Philippines; the basic social bargain as regards IR has not changed fundamentally in these countries.

Why do some of these systems adapt within the context of a stable deep structure and others transform? Although we do not have a definitive answer to this question, our cases suggest the basis for the development of an initial hypothesis in this regard. The adapters (Singapore, Malaysia, and the Philippines) are characterized by strong and activist states (Singapore and Malaysia) and/or strong employers (Malaysia and the Philippines) and either incorporated (Singapore) or weak unions (Malaysia and the Philippines) with a relatively stable economic environment. The transformers are nations whose economic environments have changed radically (India and China) or which are characterized by a combination of a strong state, strong employers, and strong unions (South Korea). We leave the testing of this tentative hypothesis to future research.

\section{Conclusion}

Our examination of a limited but representative set of Asian nations suggests that changes in IR during the 1980s and 1990s reflect the process of adjustment from a previously salient constraint (labor peace and industrial stability) to the new imperative of enhancing firm-level competitiveness through numerical and functional flexibility. The recent changes in Asian IR systems have been similar to those which have occurred in the West in that the emphasis has shifted to achieving various kinds of flexibility, although the already decentralized Asian systems have not experienced significant further decentralization. The flexibility-enhancing strategies followed by the different Asian systems, whether numerical or functional, appear to be 
mediated by the current and previous levels of IR system rigidity, sources of competitive advantage of firms, state policies and institutions, and labor unions. In some countries, the changes in IR suggest a transformation, reflecting a serious reconsideration of the deep structure of $I R$, whereas other nations have adapted to the changed constraints more smoothly and without fundamental reconsideration of the underlying logic of those systems. In general, the shift in constraints, attributable to increased competitive pressure, is pushing IR arrangements in Asia in the same direction as it has in the West, which suggests the possibility of convergence.

\section{REFERENCES}

AMRC. 1998. Asian Labor Update, 23-28. Hong Kong: Asia Monitor Resource Center.

Ariffin, Rohanna. 1997. "Changing Employment Structures and Their Effects on Industrial Relations in Malaysia." Economic and Labour Relations Review 8 (June):44-56.

Armingeon, Klaus. 1994. Staat und Arbeitsbeziehungen: ein internationaler Vergleich. Opladen: Westdeutscher Verlag.

Arudsothy, Ponniah, and Craig Littler. 1993. "State Regulation and Fragmentation in Malaysia." InOrganized Labor in the Asia-Pacific Region: A Comparative Study of Trade Unions in Nine Countries, edited by Stephen Frenkel. Ithaca, NY: ILR Press.

Barranco-Fernando, Nenita. 1994-1995. "Globalization and Its Impact on the Philippine Labor Market." Philippine Journal of Labor and Industrial Relations 16(1-2):69-98.

Becker, Brian, and Yang Gao. 1989. "The Chinese Urban Labor System: Prospects for Reform." Journal of Labor Research 10(4):410-28.

Benson, John. 1998. "Labour Management During Recessions: Japanese Manufacturing Enterprises in the 1990s." Industrial Relations 29(3):207-20.

Berggeren. Christian. 1993. "Toward Normalization? Japanese Competitive Position and Employment Practices after the Heisei Boom." Paper presented at the Industrial Relations Research Association Annual Meeting, Washington, DC.

Bhattacherjee, Debashish. 2001. "Organized Labor and Economic Liberalization: Past, Present, and Future." Paper prepared for the ILO Conference on Trade Unions and Globalization, Geneva, April 19-21, 2001.

Bray, Mark, and Nigel Haworth. 1993. Economic Restructuring and Industrial Relations in Australia and New Zealand. Monograph no. 8. Sydney: Australian Centre for Industrial Relations Research and Teaching.

Brown, Clair, Yoshifumi Nakata, Michael Reich, and Lloyd Ulman. 1997. Work and Pay in the United States and Japan. New York: Oxford University Press.

Chan, J. C. M, N. Y. Li, and D. Sculli. 1989. "Labour Relations and the Foreign Investor in the Shenzen Special Economic Zone of China." Journal of General Management 14(4):53-61.

Chan, Anita. 1995. "Chinese Enterprise Reforms: Convergence with the Japanese Model." In Future Prospects of Chinese Socialism: Eastern Europe or the Four Small Dragons? edited by B. McCormick and J. Unger. Armonk, NY: M. E. Sharpe.

. 1998. "Labor Relations in Foreign Funded Ventures, Chinese Trade Unions and the Prospects for Collective Bargaining." In Adjusting to Capitalism: Chinese Workers and the State, edited by Greg O'Leary. Armonk, NY: M. E. Sharpe.

- and Robert A. Senser. 1997. "China's Troubled Workers." Foreign Affairs 76 (March):104-17.

Chew, S. B. and Rosalind Chew. 1995. "Impact of Development Strategy On Industrial Relations in Singapore." In Employment Relations in the Growing Asian Economies, edited by Anil Verma, Thomas A. Kochan, and Russell Lansbury, pp. 158-93. London: Routledge. 
Child. John. 1995. "Changes in the Structure and Prediction of Earnings in Chinese State Enterprises During the Economic Reform." International Joumal of Human Resource Management (February).

Chiang, T. B. 1988. "The Administration and Enforcement of Collective Agreements in Singapore." In The Adminstration and Enforcement of Collective Agreements: A Survey of Collective Agreements in ASEAN, pp. 239-46. Bangkok: International Labor Organization.

Chiu, Stephen, and Stephen Frenkel. 2000. Globalization and Industrial Relations and Human Resources Change in China. Bangkok: ILO Regional Office for Asia and the Pacific.

Cook, Maria. 1996. Organizing Dissent: Unions, the State, and the Democratic Teachers' Movement in Mexico. University Park, PA: Pennsylvania State University Press.

Crouch, Colin. 1993. Industrial Relations and European State Traditions. New York: Clarendon Press.

Cusumano, Michael M. 1985. The Japanese Automobile Industry: Technology and Management at Nissan and Toyota. Cambridge, MA: Harvard University Press.

Das, Subesh. 2000. "Trade Union Density in India." Working paper, Department of Collective Bargaining, Labor Law and Labor History, Cornell University.

DeSousa, Valerian. 1999. "Colonialism and Industrial Relations in India," In The Insititutionalization of Industrial Relations in Developing Nations, edited by Sarosh Kuruvilla and Bryan Mundell. The Organizational Behavior and Industrial Relations Research Series. Stamford, CT: Jai Press.

Deyo, Frederic C. 1981. Dependent Development and Industrial Order: An Asian Case Study. New York: Praeger.

- 1989. Beneath the Miracle: Labor Subordination in the New Asian Industrialism. Berkeley: University of California Press.

. 1997. "Labor and Post-Fordist Industrial Restructuring in East and Southeast Asia." Work and Occupations 24(1):97-117.

Dore, Ronald. 1986. Flexible Rigidities: Industrial Policy and Structural Adjustment in the Japanese Economy, 1970-1980. London: Athlone Press.

Dunlop, John. 1958. Industrial Relations Systems. London: Holt.

Employment Provident Fund Act. 1972. Government of India.

Erickson, Christopher L., and Sarosh Kuruvilla. 1995. "Critical Junctures in the Transformation of Industrial Relations Systems." Paper presented at the Third Bargaining Conference, Toronto, Canada, May.

— and - 1998a. "Industrial Relations System Transformation." Industrial and Labor Relations Review 52(1):3-21.

— and - 1998b. "Industrial Relations Implications of the Asian Economic Crisis." Perspectives on Work 2(2):42-8.

$\longrightarrow,-$, Rene Ofreneo, and Ina Ortiz. 2000. "Recent Developments in Industrial Relations in the Philippines." Working paper, Department of Collective Bargaining, Cornell University.

Frenkel, Stephen. 1988. "Containing Dualism through Corporatism: Changes in Contemporary Industrial Relations in Australia." Bulletin of Comparative Industrial Relations (Special Issue on Economic Restructuring and Industrial Relations) 20:113-45.

_ and David Peetz. 1998. "Globalization and Industrial Relation in East Asia: A Three-Country Comparison." Industrial Relations 37(3):282-310.

Freund, Elizabeth, M. 1998. "Downsizing China's State Industrial Enterprises." In Adjusting to Capitalism: Chinese Workers and the State, edited by Greg O'Leary. Armonk, NY: M. E. Sharpe.

Gerlach, Michael L. 1992. Alliance Capitalism: The Social Organization of Japanese Business. Berkeley: University of California Press.

Golden, Miriam A., Michael Wallerstein, and Peter Lange. 1997. "Unions, Employer Associations, and Wage-Setting Institutions in Northern and Central Europe, 1950-1992." Industrial and Labor Relations Review 50(3):379-401.

Gordon, Andrew. 1985. The Evolution of Labor Relations in Japan: Heavy Industry, 1853-1955. Cambridge, MA: Harvard University Press.

Grace, Elizabeth. 1990. Short Circuiting Labor: Unionizing Electronic Workers in Malaysia. Kuala Lampur: Insan. 


\section{4 / Sarosh Kuruvilla and Christopher L. Erickson}

Grenier, Jean-Noel, Anthony Giles, and Jacques Belanger. 1997. "Internal versus External Labor Flexibility: A Two Plant Comparison in Canadian Manufacturing." Relations Industrielles 52(4):683-711.

Han, Jianwei, and Motohiro Morishima. 1992. "Labor System Reform in China and Its Unexpected Consequences." Economic and Industrial Democracy 13:233-61.

Hiers, Wesley, and Arudsothy, Ponniah. 1999. "From Ostensible Voluntarism to Interventionism in Malaysian Industrial Relations. The Colonial Experience as an Important Variable." In The Institutionalization of Industrial Relations in Developing Nations, edited by Sarosh Kuruvilla and Bryan Mundell. The Organizational Behavior and Industrial Relations Research Series. Stamford, CT: Jai Press.

_- and Sarosh Kuruvilla. 2000. Globalization and Industrial Relations and Human Resources Change in India. Bangkok: ILO Regional Office for Asia and the Pacific.

Hyman, Richard. 1994. "Industrial Relations in Western Europe: An Era of Ambiguity?"' Industrial Relations 33(1):1-24.

Jackson, Sukhan. 1994. "Labour Reforms in China." In Contemporary Developments in Asian Industrial Relations, edited by S. Jackson. UNSW Studies in HRM and IR in Asia No. 3. Kensington, New South Wales: Industrial Relations Research Centre, University of New South Wales.

and Craig Littler. 1991. "Wage Trends and Policies in China: Dynamics and Contradictions." Industrial Relations 22(1):5-19.

Jacoby, Sanford M. 1993. "Pacific Ties: Industrial Relations and Employment Systems in Japan and the United States since 1900." In Industrial Democracy in America: The Ambiguous Promise, edited by H. J. Harris and N. Lichtenstein. Cambridge, England: Cambridge University Press.

Japan Labor Bulletin 37(11), November 1998.

Japan Labor Bulletin 2000.

Katz, Harry C. 1993. "The Decentralization of Collective Bargaining: A Literature Review and Comparative Analysis." Industrial and Labor Relations Review 47(1):3-22

__ Sarosh Kuruvilla, and Lowell Turner. 1994. "Trade Unions and Collective Bargaining." In Impediments to Competitive Labor Markets: An Overview of Policy and Research Issues. Washington: World Bank.

Kenney, M., and R. Florida. 1994. "Japanese Maquiladoras: Production Organization and Global Commodity Chains." World Development 22(1):27-44.

Kim, Taigi. 1990. The Political Economy of Industrial Relations in South Korea. Seoul: Korea Labor Institute.

. 1995. "Human Resource Management for Production Workers in Large Korean Manufacturing Enterprises." In Industrialization and Labor Relations: Contemporary Research in Seven Countries, edited by Stephen Frenkel and Jeffrey Harrod, pp. 216-35. Ithaca, NY: ILR Press.

Kim, Young Kee. 1997. "Industrial Relations/Human Resources Practices of the LG Group." Paper presented at the International Symposium on Changing Approaches to Industrial Relations and Human Resources in the Asia-Pacific, including Australia, Korea, and New Zealand, Griffith University, Brisbane, Australia.

Kim, Y. B., and C. Leggett. 1998. "Industrial Relations in the Republic of Korea." In International and Comparative Industrial Relations, edited by Greg Bamber and Russel L. Lansbury, pp. 275-93. Boston: Allen and Unwin.

Kochan, Thomas, Harry C. Katz, and Robert McKersie. 1986. The Transformation of American Industrial Relations. New York: Basic Books.

Krislov, Joseph, and Chris Leggett. 1985. "Singapore's Industrial Arbitration Court: Changing Roles and Current Prospects." Arbitration Journal 40(1):18-23.

Kuruvilla, Sarosh. 1996. "The Relationship Between Economic Development Strategies and Industrial Relations: India, Malaysia, Singapore and the Philippines." Industrial and Labor Relations Review 49(4):635-57. 
and Rodney Chua. 1999. "How Do Nations Upskill their Workforces? The Case of Singapore."

Global Business Review' 1(1):1-30.

- and Bryan Mundell. 1999. Colonialism and the Institutionalization and Industrial Relations in Developing Nations. Stamford, CA: JAI Press.

and C. S. Venkataratnam. 1996. "Economic Development and Industrial Relations: The Case of South and Southeast Asia." Industrial Relations 27(1):9-23.

- and Ponniah Arudsothy. 1995. "Economic Development Strategy, Government Labor Policy and Firm Level Industrial Relations Practices in Malaysia." In Employment Relations in the Growing Asian Economies, edited by Anil Verma, Thomas A. Kochan, and Russell Lansbury, pp. 158-93. London: Routledge.

_- Christopher Erickson, Mark Anner, Rene Ofreneo, Maragtas Amante, and Ina Ortiz. 2000. Globalization and IR and HR Change in the Philippines. Bangkok: Regional Office for Asia and the Pacific.

Lee, Byoung-hoon. 2000. Personal interview.

Lee, Won_Duck. 1993. "Recent Developments in Korean Industrial Relations. Issues and Policy Directions." In Industrial Relations and Human Resource Management in an Era of Global Markets: An Asia-Pacific Perspective, edited by Thomas A. Kochan, Anil Verma, and Russell Lansbury. London: Routledge.

Leggett, C. 1993. "Corporatist Trade Unions in Singapore." In Organized Labor in Asia Pacific Region, edited by Stephen Frenkel. Ithaca, NY: ILR Press.

. 1997. "Korea's Divergent Industrial Relations." New Zealand Journal of Industrial Relations 22(1):64-73.

Lincoln, James R., and Yoshifumi Nakata. 1997. "The Transformation of the Japanese Employment System." Work and Occupations 24(1):33-55.

Littler, Craig, and Martin Lockett. 1983. "The Significance of Trade Unions in China." Industrial Relations 14(4):31-42.

Locke, Richard M. 1996. Remaking the Italian Economy. Ithaca, NY: Cornell University Press.

Macaraya, B., and R. Ofreneo. 1993. "Structural Adjustment and Industrial Relations in the Philippines." Paper presented at the Conference on Industrial Relations, September 1993, University of New South Wales, Sydney, Australia.

Mathur, Ajeet. 1993. "The Experience of Consultation during Structural Adjustment in India (19901992)." International Labor Review 132(3):331-45.

Morishima, Motohiro. 1998. "Changes in Japanese Human Resource Management: Implications for Firm Performance." Paper presented at Sixth Bargaining Group Conference, May, Champaign, IL.

. 1999. "The Role of Labor in the Recent Changes in White-Collar HRM Practices in Japan." Japan Labor Bulletin 38(12):6-13.

Nakamura, Keisuke, and Michio Nitta. 1993. "Developments in Industrial Relations and Human Resource Practices in Japan." Working paper, Department of Collective Bargaining, Cornell University, March.

O'Leary, Greg. 1994. "The Contemporary Role of Chinese Trade Unions." In Contemporary Developments in Asian Industrial Relations, edited by Sukhan Jackson. UNSW studies in HRM and IR in Asia No. 3. Kensington, New South Wales: Industrial Relations Research Centre, University of New South Wales.

__ 1998. "The Making of the Chinese Working Class." In Adjusting to Capitalism: Chinese Workers and the State, edited by Greg O'Leary. Armonk, NY: M. E. Sharpe

Ofreneo, R. 1994. "Labor and the Philippine Economy." Unpublished manuscript, University of Philippines, School of Labor and Industrial Relations.

—_ and I. Ortiz. 1998. "Globalization and Employment Relations in the Philippines." Working paper, School of Labor and Industrial Relations, University of the Philippines.

Okayama, R. 1986. "Industrial Relations in the Japanese Automobile Industry, 1945-1970: The Case of Toyota." In The Automobile Industry and its Workers, edited by S. Tolliday and J. Zeitlin. Oxford, England: Polity Press. 


\section{6 / Sarosh Kuruvilla and Christopher L. ERickson}

Park, Young-Bum, and Michael Byungnum Lee. 1993. "Economic Development, Globalization, and Practices in Industrial Relations and Human Resources Management in Korea." In Industrial Relations and Human Resource Management in an Era of Global Markets: An Asia Pacific Perspective, edited by Russell Lansbury, Thomas A. Kochan, and Anil Verma. London: Routledge.

Park Cha-Gyu. 1998. "The Impact of the IMF Bailout on IR/HR Systems and Practices: The Korean Experience." MPS thesis, Cornell University.

Peetz, David, and Trish Todd. 2000. Globalization and Employment Relations in Malaysia. Bangkok: ILO, Regional Office for Asia and the Pacific.

Piore, Michael J., and Charles F. Sabel. 1984. The Second Industrial Divide: Possibilities for Prosperity. New York: Basic Books.

Pucik, Vladimir, and Juncheol Lim. 1996. "Human Resource Management in Korea: The Changing Roles of the Chaebol's HRM System." Working paper, Center for Advanced Human Resource Studies, Cornell University.

Ramaswamy, E. A. 1983. Indian Management Dilemma: Economic Versus Political Unions. Asian Survey 23(8):976-90.

Ramos, Elias. 1981. "Philippines." In International Handbook of Industrial Relations, edited by Albert E. Blum, pp. 4430. Westport, CT: Greenwood.

Rosa, L. 1990. "The Singapore State and Trade Union Incorporation." Journal of Contemporary Asia 20(4):487-508.

Salih, Kamal, Rasiah Rajah, and Mei Ling Young. 1988. Transnational Capital and Local Conjecture: The Semiconductor Industry in Penang. Kuala Lampur: Malaysian Institute for Economic Research.

Seung, Wook Baek. 2000. "The Changing Trade Unions in China." Journal of Contemporary Asia $30(1): 46-66$.

Sharma, Basu. 1996. Industrial Relations in ASEAN: A Comparative Study. Fredericton, New Brunswick, Canada: Management Futures.

Shimokawa, Koichi. 1998. "Direct Investment and the International Division of Labor in the Japanese Automobile Companies in Asia." Paper presented at the 1998 Asian Regional Conference on Industrial Relations, Japan Institute of Labor, Tokyo, March.

Shin, Joon Shik, and Nick Wailes. 1997 "The Korean Confederation of Trade Unions: Independent Unionism in Newly Industrializing Countries." Paper presented at the International Symposium on Changing Approaches to Industrial Relations and Human Resources, Griffith University, Brisbane, Australia.

Siegel, J. 1999. "Collapsing Pillars in Japan." Paper presented at the 51st Annual Meeting of the Industrial Relations Research Association, New York, January 2-5.

Sodhi, J. S. 1993. "New Economic Policies and their Impact on Industrial Relations." Indian Journal of Industrial Relations 29(1):31-54.

Streeck, Wolfgang. 1988. "Industrial Relations in West Germany, 1980-1987." Labour 2(3):3-44.

Taira, Koji. 1970. Economic Development and the Labor Market in Japan. New York: Columbia University Press.

Takahashi, Yukichi. 1997. "The Labor Market and Lifetime Employment in Japan." Economic and Industrial Democracy 18:55-66.

Toyonaga, Mami. 1998. "Change in the Structure of Employment in the Japanese Electric Machine Industry: Do Asian Affiliates Affect Employment?" Paper presented at the 1998 Regional Conference on Industrial Relations, Japan Institute of Labor, Tokyo, March 14-18.

Ungson, Geraldo, Richard M. Steers, and Seung-Ho Park. 1997. Korean Enterprise: The Quest for Globalization. Boston: Harvard Business School Press.

Villegas E. 1988 The Political Economy of Philippine Labor Laws, pp. 38-51. Quezon City, Philippines: Foundation for Nationalist Studies.

Venkataratnam, C. S. 1993. "Impact of New Economic Policies on the Role of Trade Unions." Indian Journal of Industrial Relations 29(1):56-77.

, 1997. "Overview: Globalization and Labor Management Relations in South Asia". Paper presented at Regional Industrial Relations Conference Organized by the South Asia Multidisciplinary 
Advisory Team, ILO, and the Indian Industrial Relations Research Association, New Delhi, India, December.

Warner, Malcolm. 1987. "Industrial Relations in the Chinese Factory," Industrial Relations 29(2): $217-32$.

Wilkinson. B. 1994. Labour and Industry in the Asia-Pacific: Lessons from the Newly-Industrialized Countries. New York: DeGruyter.

Woo, Seoghun. 1997. "Approaching the 21st Century: Perspectives on Korean Industrial Relations." Economic and Labour Relations Review, 8(June):22-43.

World Bank. 1998. World Development Indicators, 1998. Geneva: World Bank.

Yamakawa, Ryuichi. 1999. "The Silence of Stockholders: Japanese Labor Law from the Viewpoint of Corporate Governance." Japan Labor Bulletin 38(11):6-12.

Zhao, Minghua, and Theo Nichols. 1998. "Management Control of Labor in State-Owned Enterprises: Cases from the Textile Industry." In Adjusting to Capitalism: Chinese Workers and the State, edited by Greg O'Leary. Armonk, NY: M. E. Sharpe. 